Article

\title{
Evaluation and Classification of Mobile Financial Services Sustainability Using Structural Equation Modeling and Multiple Criteria Decision-Making Methods
}

\author{
Komlan Gbongli ${ }^{1, *} \mathbb{1}$, Yongan $\mathrm{Xu}{ }^{2, *}$, Komi Mawugbe Amedjonekou ${ }^{3}$ and Levente Kovács ${ }^{1}$ \\ 1 Institute of Finance and Accounting, Faculty of Economics, University of Miskolc, 3515 \\ Miskolc-Egyetemvaros, Hungary; kovacs.levente@uni-miskolc.hu \\ 2 School of International Business, Southwestern University of Finance and Economics, 55 Guanghuacun \\ Street, Qingyang District, Chengdu 610074, China \\ 3 Business School, York St John University, Lord Mayor's Walk, York Y031 7EX, UK; \\ komi.amedjonekou@yorksj.ac.uk \\ * Correspondence: samxp12@yahoo.fr or pzkgbong@uni-miskolc.hu (K.G.); xyan88@swufe.edu.cn (Y.X.)
}

Received: 23 December 2019; Accepted: 5 February 2020; Published: 11 February 2020

check for updates

\begin{abstract}
Despite the fast emergent of smartphones in day-to-day activity, the sustainable development of mobile financial services (MFS) remains low partially due to online consumer's trust and perceived risk. This research broadens the trust and the perceived risk at the multi-dimensional for understanding and prioritizing alternatives of MFS decision. A combined methodology; structural equation modeling (SEM) with two multiple criteria decision-making (MCDM) methods such as a technique for order of preference by similarity to ideal solution (TOPSIS) and analytic hierarchy process (AHP) were applied for data analysis. The two steps SEM-TOPSIS techniques were adopted through a two-types survey on datasets consisting of 538 MFS users, and 74 both experienced MFS users and experts in Togo. The SEM is used for causal relationships and assigning weights for the TOPSIS input. TOPSIS was applied for providing MFS alternative classification, in which the results were compared with prior research using the SEM-AHP technique on the given population. The results via SEM revealed particularly strong support for the dispositional trust and perceived privacy risk. Trust has a negative relationship with perceived risk. Except for perceived time risk, all the antecedents of perceived risk and trust validated the proposed relationship. The findings of TOPSIS uncovered that mobile money transfer (MMT) remains the core application used, followed by mobile payment (MP) and mobile banking (MB) and, therefore, consistent with AHP. However, the TOPSIS technique is better suited to the problem of MFS selection for this study field. This research offers a novel and practical modeling and classification concept for researchers, companies' managers, and experts in the areas of information technology. The implications, limitations, and future research are provided.
\end{abstract}

Keywords: mobile financial services (MFS); trust; perceived risk; structural equation modeling (SEM); multiple-criteria decision-making (MCDM); technique for order preference by similarity to ideal solution (TOPSIS); analytic hierarchy process (AHP)

\section{Introduction}

As a part of the shift of technology in the financial business, mobile financial services have been exploring at an accelerate speed [1]. Innovations and technological expansion have emerged with significant advantages to the recent commercial market. Over the past few years, businesses have been redirecting their goals to making information system technology an essential part of their processes [2]. 
Therefore, more and more literature is diverted to the IS-related field [3]. The investigation of some existing studies which recommend integrating various theoretical models to understand the IT adoption has stressed that a comprehensive analysis in the context is required [2,4]. From these perspectives, an increasing number of researchers are focused on mobile financial services (MFS) considered as the development of the information system (IS) domain [5-8].

MFS refers to any financial transaction remotely conducted by the application of a mobile phone (e.g., smartphone or tablet) and mobile software (e.g., apps programs) either through banking service or network provider service $[9,10]$. MFS providers allow their consumers the flexibility to access their financial services (access information inquiry, bill payment, and money transfers) anywhere and anytime via a mobile phone, to support and improve service relationships by investing lots of resources using wireless Internet technology [11].

The studies of MFS that emphasized on electronic money transfer include three major mobile technologies-related fields of study, primarily mobile banking services (MB), mobile payment services (MP), and mobile money transfer (MMT) services [10]. MB remains part of the latest in a sequence of new mobile technological wonders [12]. Therefore, an expectation toward it should be for a significant impact on the market [13]. Payment today has now progressed to mobile devices (m-devices) identified as mobile financial services, particularly mobile payments [14]. Mobile money has appeared as a significant innovation with a potential expansion to financial inclusion in developing countries in various ways [15]. It is, therefore, growing access to financial services for a large number of people, who are entirely disregarded by banks because of longer travel distances or insufficient funds to fulfill the minimum deposit recommended for opening account in a bank $[16,17]$, low-income population in developing countries [18], insofar, as it has several advantages [15,19,20]. In addition to the advantages granted to certain persons and companies, there are also advantages at the national economy level, primarily in emerging economies such as Hungary. The use of increasingly more accommodating tools may incentivize the suppressed use of cash, parallel to which, the countability of economic performance with statistical instruments continues to improve; meanwhile tax payment discipline also improves and the total social cost of payments decreases, etc., that is, overall the economy begins to whiten, leading to improved competitiveness [21].

While tremendous benefits are associated with adopting MFS as opposed to traditional payment methods, such as physical exchange notes, cheques, coins [18], the adoption rate is far from full utilization in many developing countries. This is characteristically the situation of West African Countries and particularly Togo. Given the statistical information on the Statista Portal (2016), the population using smartphones worldwide is predicted to be over five billion marks in 2019 . Approximately $67 \%$ of the Togolese population subscribed to the mobile phone in 2015, while users of mobile Internet doubled between 2014 and 2015. However, the percentage rate of users of banking services is less than $15 \%$ [22] and, the rate of consumer acceptance of mobile banking remains trivial (around 1\%) when considering the expectation [23]. It is, therefore, leading to deduct that mobile money services should fill this lacuna by providing significant input to increase the acceptance of MFS. This hope is far from being the case. The experiences of more developed countries also suggest the same, not technological limitations were the primary obstacle of the extension of the innovative payment solutions [24]. Therefore, the motives for the successful evolution or not together with the causes and motives for mobile money adoption, remain not understood sufficiently, which infers that the technology has not been extensively adopted. These trends reveal partial knowledge regarding the motivators and inhibitors that impact the acceptance of this mobile service [25].

Understanding why it is worth to select to use MFS can help in strategy development and allow businesses to effectively communicate benefits to their customers [26,27]. Mobile financial service operators might increase their attractiveness and competitiveness if they were able to enhance their strategies to satisfy the demand of their consumers. Therefore, there is a necessity of understanding the various requirements of MFS users and the comparative weight of each factor or criteria that could affect the demand of consumers. One possible motive for the existence of a gap between these could 
be the perception of risk that limits consumers' capability to make informed decisions to partake the benefit of MFS technology in Togo [28]. This is particularly true for emerging nations, mainly in an unstable country where the consideration of the loss of privacy in the security system and the associated risk played a crucial part in adopting IT [29]. Moreover, the studies in the past revealed that once there are risk issue concerns, the demand for trust becomes a necessity, since trust and risk are interrelated facets $[28,30]$. Not only the developing countries facing the issue of e-business but also the reflection of the online risk has called for a considerable attention among the developed countries like Hungary, particularly in 2014 when the case of fraud risk in electronic payment transactions ascended in Hungary (the case was discussed in the work of Kovács and David in detail [31]).

Driven by studies toward the multiple scopes for risk and trust and the central research on trust in contrast to risk in novel information technology perspective [32], we suppose that initiating research into novel IT artifacts such as this research could enlighten how trust and perceived risk could influence the ultimate adoption of novel technologies in developing countries.

The goal of this study is to disclose mechanisms related to behavior associated with MFS adoption and sustainable development when decision-making involves multiple criteria issues. One main research question is to understand how multi-dimensional trust and multi-faceted perceived risk perceptions affect a new emerging information technology such as MFS adoption at the individual level in an unstable country. Our approach differs from most prior studies that assess trust and risk perception of individual behavior. Indeed, most of the research that investigated the acceptance and application of communicative IT has been done within stable, capitalist, and highly-developed communities. Moreover, the majority of research undertakes that individuals have freedom of speech, and safety of their lives, basic protection and business offered by the government. However, little has been known regarding the adoption of IT in emerging and dynamic societies [33,34]. Therefore, we explore the fundamental trust and risk allied with MFS technology usage in high poverty.

The majority of prior research typically tests trust as a single construct [35-37] or investigates trust constructs and risk dimensions disjointedly $[27,38]$. In other words, how to effectively assess trust and risk concerns concurrently remains a black box. Drawing on research in information technology [39,40], we stress that multi-dimensional trust and perceived risk concepts may jointly play an integral part in individual behavior with regard to adopting a novel MFS, and it is of paramount importance for this to be investigated, particularly in developing countries such as Togo.

Furthermore, a plethora of research has been done in order to fully understand the factors that affect MFS adoption and its significance. However, most prior studies in this perspective have emphasized the general factors regarding the adoption of MFS, using explanatory statistical analysis as the research method [41,42]. The beta coefficients gained in multiple regression techniques can be considered as the relative weights of the constructs, however, their values are obtained indirectly via the testing result. Additionally, a negative value of beta can be found, making it quite complex for the justification of the importance of the resultant value [43]. Making decisions has continually been an essential activity in day to day life. Therefore, using services such as MFS necessitates a careful decision from an individual so that he/she would not regret his/her decision, ever since decision-making has emerged as a mathematical science today [44]. From there, multiple criteria decision-making (MCDM) techniques constitute a critical framework through which companies focus on which strategy to implement to meet the needs of consumers, to acquire the appropriate income, and to prosper in the competitive milieu [45].

In order to advance current IS researches, Esearch and Koppius [46] stressed that there is a necessity to integrate decision modeling methods in IS research to generate data estimates as well as methods for assessing the analytical power of the result. Therefore, applying a combined analytic method stressed how integrating two or multiple data analysis techniques in either methodology or investigation can patronize the confidence and validity in the resulting outcome [15,47]. Additionally, most managers make strategic decisions based on a single goal or dimension, but strategic planning is impacted by many different factors and regarded from several perspectives [48]. As the traditional 
notion of strategic planning lacks multidimensional prominence, this paper integrates the structural equation modeling and technique for order preference by similarity to ideal solution (SEM-TOPSIS) method to construct the relationships between decision factors for MFS adoption, while classifying the alternative of MFS. It is a unique decision support technique grounded in structural modeling.

The primary objectives of this research are: To explore the influential antecedent of trust and risk perception at the multidimensional level regarding MFS adoption in Togo; to propose and validate model MFS acceptance using an SEM technique by employing data collected through experts of MFS and MFS experienced users; to develop an SEM-TOPSIS-based model for multi-criteria decision-making by selecting the appropriate MFS type for MFS, grounded in experts' view, and by prioritizing the operative trust-risk factors while exposing the veiled relationship among the factors that influence customers in the MFS. The present study has the following contributions.

Primarily, a growing number of recent studies link the multiple criteria decision-making (MCDM) techniques to financial decision making [49]. In the majority of cases, the traditional model of MCDM considers the criteria (factors) are independently and hierarchically organized. Nevertheless, problems are often organized by interdependent criteria and dimensions and might even reveal feedback-like effects [50]. TOPSIS is one of the most extensively adopted decision methodologies in technology, engineering, management, science, and business. TOPSIS approaches, as part of MCDM, have an impact on improving the quality of decisions by generating the development more efficient, rational, and explicit. However, previous works have not sufficiently kept pace. Thus, we believe that there is a necessity for the methodical integration of SEM-TOPSIS to merge a recent study performed in this field of study. This study incorporates a complex multi-criteria decision-making problem by assessing types of multidimensional trust and risk in MFS that have rarely been investigated and touched in past studies. As such, a literature review is conducted, and then SEM analysis is used to construct a hierarchical structure for trust and risk factors, which includes a total of ten sub-factors. According to the identified criteria and sub-criteria and by considering relationships among them, TOPSIS is adopted for selecting the appropriate types of MFS, based on the critical factors that influence customers' trust and risk. Hence, the study contributes by proposing a solution that could effectively enhance trust and mitigation-perceived risk measures through a multi-level approach considered as a new added concept to planning strategy from the MFS perspective.

Second, one of the contributions of this research is based on the comparison of the results of both TOPSIS and analytical hierarchical process (AHP) technique, for a given model, to inspect if there are, indeed, noteworthy differences. The result of AHP is derived from the earlier work of Gbongli [10] in which the SEM-AHP technique has been applied for assessing the issues of risk and trust using the specified population. Similarly, the main work is derived from previous work in which SEM-TOPSIS has been extensively adopted on the equal given population [51]. As a result, this study shows that both approaches achieved comparable results and were well consistent and, in general, agreed with each other. In other words, both methods classify mobile money services as the most important MFS used, followed by mobile payment as the second and mobile banking as the last. However, the TOPSIS method is better suited to the problem of MFS selection for this study area since AHP requires a long process of pairwise comparison, and the requirement of the consistency ratio should also be considered in the process. The paper provides a detailed methodology application that could provide very useful insights for managers and researchers for their specific application.

The remainder of this paper is structured as follows. In Section 2, we offer a succinct overview of the literature and theory review. For Section 3, we present the theoretical framework. In Section 4, the description of the research methodology and the procedure of this research are presented. Section 5 provides findings based on the research objectives. We conclude the work with discussions of the findings, implications, limitations, and future study suggestions. 


\section{Literature and Theory Review}

\subsection{Understanding Mobile Financial Services (MFS)}

The rapid adoption of mobile devices in developing countries [52], together with widespread mobile financial services, has recently drawn practitioners and academics' attention [53]. Since consumers are spending gradually more and more time in online and are "going mobile," financial digitalization is now driving banks and network companies' providers to undertake the most extensive transition in their history. Mobile financial services (MFS) denotes the financial services and financial transactions performed using the channel such as mobile devices [54].

MFS characterizes an area of innovation and strategic importance for global initiatives to counter poverty and mobile telecommunication providers [55]. It has been said to have carried about a positive shift in customers' perceptions in many countries. Mobile operators grasp MFS as an opportunity to engender revenue via an adjacent business (both basic payment and services) and recovery of cost and investments through enlarged data usage by consumers [56]. The goals of MFS are accompanied by various advantages for banks, such as the decreased use of cash, while cost-effectively serving the unbanked population, protecting current accounts and products. The major benefit of MFS regarding trade involves higher point-of-sale (PoS) throughput, real-time messaging to users, and fewer cost for cash handling. Accessing transaction information and ownership of the user interface are further viewed as an important perceived value of MFS. For the customer, MFS makes payments possible anytime, anywhere, and with the alleviated risk of theft (i.e., cash, particularly in underdeveloped communities) [55].

These advantages could be equally valid for Togo. Not much attention has been given to the empirical research on the adoption of MFS in Togo. Furthermore, in less affluent nations stricken with socio-political instability and vulnerability, MFS technologies may have different implications toward usage and are likely to impact the initial decisions to adopt $[57,58]$. The country of Togo sometimes encounters a kind of socio-political crisis. Given a negative socio-political and external influence such as the physical atmosphere of development and growth, policies, regulations, and social environment unsupportive of adoption are suggested to hinder innovation adoption [59]. MFS unavoidability might confront such challenges because of consumers' lack of trust in the novel wireless technology, and their risk perceptions. We thus stress that users' trust and risk perception may impact their adoption of MFS services.

\subsection{Theory and Past Research}

As an emergent service, mobile financial services (MFS) has not been widely adopted by users. Therefore, scholars have paid attention to assess the factors impacting their user adoption. Furthermore, technology adoption is one main area of focus for information systems (IS) researchers. A diversity of theoretical perspectives has been developed to study MFS adoption. More assertively toward another direction, the current literature on consumer behavior related to acceptance of IT, such as MFS, tends to elaborate on a theoretical model of technology adoption theories [60]. They often employ the traditional information system models to explain user adoption of IT like theory of reasoned action (TRA), motivational model, diffusion of innovation theory (DOI), technology acceptance model (TAM), innovation diffusion theory (IDT), theory of planned behavior (TPB), and unified theory of acceptance and use of technology (UTAUT). Numerous studies have employed these traditional frameworks to perform their researches, and the rest integrated either previous models or added new variables to construct models to carry out their study. They examine whether the models' theoretical constructs are likely to affect the consumer acceptance of an MFS [15,61-63] or assess whether consumers are ready to adopt m-payments grounded in the supposed factors [64].

The TRA model stipulates that a particular behavior is directed by the individual's intention to conduct that action, which itself hinges on the attitude to behavior and subjective norms [65]. For the TPB model, the perceived behavior was added to the attitude toward behavior and subjective norms 
that affect both the intentions of people's perceived behavior and actual behavior [66]. Past studies elucidated behavioral perception control as the degree to which one has control over launching a particular behavior as well as facing the circumstances, while the full volitional control over the behavior of interest is found limited [67]. Although their finding pinpointed the internal and external factors of perceived control, as an example, self-efficacy and facilitating condition, technology, and government sustenance, the utmost impact on the behavior is somehow associated with the type of innovation. The TAM model, as the extension to the TRA and TPB models, bears a significance of perceived usefulness and perceived ease of use factor to affect actual behavior geared toward innovation [68]. Based on the review of TAM literature, Marangunić and Granić [69] revealed seven past TAM-related studies. However, the goal of these works and the various analysis techniques adopted differ. For instance, Legris et al. [70] examine the question of whether the TAM explains actual use while Mortenson and Vidgen [71] conducted the review of TAM studies employing the computational literature review (CLR). Moreover, TAM [72] and its extended version has been used in various online milieu to assess the adoption of consumer's online-system [15,73-75].

The TRA model, however, has some drawbacks, comprising a major threat misleading between attitudes and norms because attitudes can commonly be viewed as norms and conversely. Similarly, further explanatory variables are required for TRA [76,77]. As such, TAM has then been successfully combined with TRA and TPB in parsimonious capability [78]. The theory of adoption, such as DOI theory [79], is a handy systemic background to define either adoption or non-adoption of new technology. The theory put forward is that people will be more likely to accept innovation grounded in the innovation facets and appearance of comparative benefit, compatibility, intricacy, trialability, and observability [80]. Regardless of the enlightened strength of this model, the weaknesses go a long way in decreasing its power. For instance, the relationship between attitude and espousal or rejection of innovation was restricted [81,82]; the innovation-decision process and the features of innovation remain unclear as well. The theory posits technology to pass via a linear stage; however, an intricate technology [83] has been perceived not on linear stages. Rendering to the critical review and meta-analysis of TAM [70], it was suggested as a useful model; although, it suffers from the trade-off of dropping information richness resulted from the investigation [84].

Despite the various advantages that might be incorporated into every theory or model, their competency in predicting and elucidating is due to the degree to which the predictor could get a sound proportion of variance explained in intention and usage behavior $[85,86]$. Even though the prevailing models are indicative of e-service or MFS acceptance behavior, many researchers believe that they are not sufficiently robust with regard to assessing all the aspects clients intend obviously throughout the various phases of their decision-making process and thus require further integration [87]. George's findings [88], after the review of previous information acceptance models, revealed that trust consideration could be a major laudatory and backup for an online vendor.

It is important to recall that trust and risk are interrelated facets [30], where the degree of importance of the situation depends on the impending outcome of risk. Given that the adoption of MFS becomes an important decision that consumers are required to make for a long-term impact, the function of risk is more likely to be vital. The extensive review of the literature revealed diverse antecedents to the adoption of mobile banking [27,89-92]. Studies were carried out in both developing and developed countries; however, a limited number have been conducted in Togo [7,93]. These outcomes are, therefore, insufficient to offer meaningful insights into predicting which multi-dimensional trust and risk influence customers' use of MFS in Togo while providing a strategy decision analysis framework for understanding the multiple factors that entail the decision of the acceptance. Moreover, many of these theories and models were used in developed countries, and their direct application in developing countries such as Togo might not be sufficiently robust for the economic situation of the country. Given that MFS belongs to information technology to which some adoption model might exist, it requires a distinctive conceptualization that might better pronounce the fact in emerging countries' situations. 
Regarding these ends, this study uses components from both trust and risk dimensionality literature. It proposes conceptual research to envisage consumer appraisal of MFS (mobile banking, mobile payment, and mobile money transfer) adoption in Togo while ranking their perspective.

\section{Theoretical Framework and Hypotheses}

\subsection{Antecedent of Trust}

The concept of trust remains an intricate, multi-dimensional, and context-dependent paradigm [94]. Past researchers emphasize the diverse aspects of trust, a fact that frequently leads to discrepancies between numerous studies outcomes. After the appeal from Gefen et al. [32] for additional new IT-related research on trust, there is a need to collectively assess the most crucial trust's dimension, such as a disposition to trust, technology trust, and vendor trust that seems to impact MFS.

Some scholars have proposed trust dispositional, trust belief, structural assurance [95]. From others' point of view, the interpersonal trust, the dispositional trust, and institutional trust are also essential constituents of the trust dimension [96]. Others found the dimension of trust to be trusting behavior, dispositional to trust, and institution-based trust [97]. Disposition to trust denotes the general susceptibility for a person to trust others [98]. It is grounded in the personality, which explains the reason why some of us have a tendency to either trust or mistrust and doubt others [99,100]. Disposition to trust is, therefore, crucial for the establishment of initial trust and subsequently accommodating to less importance in the presence of pre-existed trust belief [101].

Technology trust is considered as an antecedent of trust. It connotes the readiness of an individual, or individual's technological dependency, to achieve a designated task by the positive feature incorporated in the technology [102] and the benefit arises from the particular technology [103]. With this view, technology trust refers to the role of technology in building a trusting relationship with the user [104]. From the above perspective, when an MFS user considers the technologies that are being applied to be reliable and consistent, then the probability to assess the aggregate service seems more promising, and trust will increase. Although admitting that the three-fold technology aspect affects the environment of MFS (i.e., website, network, and mobile technology), the present study intends to treat them as a whole without separating them. As such, the user or potential user is called upon the strong level of comprehensive understanding purposively for MFS optimum usage. Past research has revealed much importance and many benefits of technological trust in the behavioral field of application [102,105-107].

Vendor trust denotes the extent to which the consumer sees and believes that the vendor will accomplish the designated transactional requirements in risky or ambiguous conditions [108]. Many situations can raise consumer's trust toward the vendor. An online consumer who perceives the vendor in presenting an opportunistic behavior can create a kind of reluctance within that particular consumer. Earlier studies have revealed a negative relationship between the online vendor's opportunism and online consumer's trust [109]. Trust, and in specific the confidence in the mobile vendor, plays an exceptionally important role in the digital environment [110-113]. For Roger C. Mayer et al. [114], vendor ability, integrity, and benevolence are crucial vendor trust features, although ability can also be regarded as vendor competence [115]. By relating that logic to the MFS environment, vendors with a good reputation/integrity will be less expected to bear unscrupulous behaviors and threaten their status. As a result, we posit the succeeding three assumptions to inspect the causal effect relationships between trust's antecedents and trust in the MFS perspective.

Hypothesis 1. The dispositional trust would significantly influence users' general trust in using MFS.

Hypothesis 2. The technological trust would significantly influence users' general trust in using MFS.

Hypothesis 3. The vendor trust would significantly influence users' general trust in using MFS. 


\subsection{Antecedent of Perceived Risk}

Perceived risk can denote a combination of uncertainty added to the severity of the consequence involved [116]. It is similarly taught as a kind of uncertainty and outcome [117]. In the psychological field, perceived risk is the emotional sensitivity and subjective thoughts of various objective risks. Although it is the derivative of the objectives risk, nevertheless, they are different from each other. From the perceptive of trust-risk relationship, prior researchers understood that the readiness to take risks is a general characteristic of all trust circumstances $[28,118,119]$. From this point, consumer trust could be noticed and subjected to the degree of the intricate risk presented in the situations [120]. Awkwardly perhaps, because of the complex nature of trust and risk variables, countless scholars have disregarded the function of risk perceptions [121]. E-commerce trust investigators have shown that, when trust increases, the trustee's perception of risk reduces and impacts their attitudes to the trustor, which successively, influences the readiness to procurement [122]. In the view of the risk management field, the risk is the construct associated with the cost of outcomes, empowering trust and risk as mirror images while both incorporate differing relationships [123]. The study focuses on the rapport among trust and risk [121], and the trust-related works and empirical confirmation predominantly emphasize on industrial relationships, nonetheless theoretical and empirical support encountered in MFS is limited. When people trust others, they believe that those they trust will act as anticipated, which diminishes the intricacy of the interaction. Understanding the high convolution of the relationship between trust and risk concept, and considering likewise the absence of scholarly unanimity that lack on how to account their relationship via model [124], this study takes the view of a mediating relationship [121] instead. On the mediating standpoint, if trust exists, then the risk perceived is reduced, which successively will impact the degree of decision-making to use MFS. Thus, higher trust in a technology would lower its perceived risk and consequently positively affect behavioral intention [125].

These ideas of risk and others will endure a detrimental dominance on the acceptance of MFS. For instance, Swaminathan et al. [126] revealed consumers' opposition to providing their credit card information through the Internet. With MFS, the consumers are required to entrust not only their credit card information but a whole account of information in most cases. Wide-ranging, trust ameliorates the consumer's conception toward online service and the related component, diminishing the level of the risk perception allied with the transaction process.

From the attribute of risk opinion, a plethora of researchers brought that studies on consumer's risk perception are a kind of a multi-facet concept $[28,39,127]$, which becomes the root of the aggregate perceived risk. To date, perceived risk has been employed to elucidate both offline and online risk shopping behavior. The finding derived from the work of Featherman and Pavlou [127] on the consumer's adoption of e-services has been widely accepted, which classified perceived risk dimensions as an economic risk, social risk, time risk, functional risk, psychological risk, and privacy risk. Bellman et al. [128] informed regarding the prominence of time concerns and argued that it is a substantial predictor of online buying behavior. According to the finding, consumers in a hurry who have less time are more plausible to buy on the Internet. The perception of time risk can refer to the integration of time lost and determination expended in acquiring any item and service [129]. Grounded in this similar logic, the current study proposes that consumers are time-oriented, time-conscious, and therefore value the potential time they might spend in implementing, searching and learning the application process of the new MFS.

Security/privacy risk is categorized as an intrinsic loss undeviatingly to fraud, scam, or hacktivists haggling the security of the user of an e-service [130]. The security or privacy issues mostly arise when a customer is transferring money from his/her account or dealing with his/her secluded economic information, whereas others view this information without his/her consent. The perception of costs applied to the MFS application reveals fear among the consumers. Empirical evidence stressed that mobile banking acceptance is highly sustained by economic aspects such as beneficial fees regarding transaction service [131]. Alternatively, it is impeded by economic considerations (issues centered on basic 
fees for assessing mobile banking), like cost burden [132] or high payment incorporated in using mobile banking [133]. Therefore, the perception of cost risk tends to negate the adoption of mobile banking [134].

Centered on the work of Featherman and Pavlou [127] predominantly, and throughout the previous studies toward risk components so far; the present study deduces four important dimensions of risk perceived, which are expected to influence the consumer's overall risk concerning the MFS adoption. They are the perceived privacy risk, time, security, and financial risk in the form cost perceived. Hence, we can posit the following assumption based on the discussion being done under this section.

Hypothesis 4. Consumer's general trust would negatively associate with the perceived risk in MFS.

Hypothesis 5. Perceived privacy risk would significantly influence users' perception of risk of using MFS.

Hypothesis 6. The Perception of time risk would significantly influence users' perceived risk of MFS.

Hypothesis 7. Perception of security risk would significantly influence users' perceived risk of MFS.

Hypothesis 8. Cost perceived would significantly influence users' aggregate perceived risk of using MFS.

\subsection{Antecedents of MFS Adoption}

Under this section, three antecedents (dispositional trust, trust, perceived risk) of MFS adoption will be taken into consideration. Being part of a personality trait, a disposition to trust can denote an individual's predilection to show reliance on humanity and to support a trusting standpoint concerning others $[135,136]$. Many researchers hypothesize the disposition to trust as partaking a positive impact on trust toward online shopping websites [136]. This relationship was also supported in various IS research, particularly in e-commerce [94,137,138], and in mobile banking [139]. Accordingly, Gefen et al. [101] pointed out that disposition to trust is crucial, particularly for the development of early trust and befits less significant for established trust or pre-existing relationships trust beliefs. Once encountering people with trifling or no experience using the wireless Internet as a platform for financial transactions, a disposition to trust is predictable to affect their trusting perception on the Internet. People partaking high disposition to trust are more favorable to feel relaxed or secured when using wireless Internet for financial transactions [39]. Inferring from this lucidity to the MFS, we expect that consumers having a higher disposition to trust are more probable to espouse MFS than those with a lower disposition to trust.

The next antecedent of MFS adoption resides in risk perception. Since its application among consumer behavior literature [116], the conception of perceived risk has been reviewed from a multiplicity of viewpoints. The classical decision concept considers risk perception as a function of the distribution of probable outcomes of conduct, its likelihoods, and subjective values [140]. Accordingly, risk encompasses two dimensions: uncertainty and outcome, where there is the possibility of experiencing a loss as a consequence of a behavior and the significance accredited to the loss [141,142]. While various researchers have criticized this approach because of its strictness to apprehend a perceived risk variable equally to be ambiguous and indistinct [142], some others were heightened to this concept definition as expected utility theory $[143,144]$. Explicitly risk, therefore, carries on the subjectively driven expectancy of loss by the customer when denoting the perceived risk [145]. Internet banking and MFS, predominantly mobile banking, rely on a similar type of risk [146], only, the information media channels differ. Prior IS studies showed that the imperative attitudinal of perceived risks impact adoption behavior where much is based on the privacy risk and transaction security risk [6,147-150]. Preceding studies have equally supported the negative effect of the perceived risk of online usage and purchasing behavior [151-154]. Likewise, earlier researchers agreed that the more risk is perceived by someone in purchasing context, the less probable he/she will be resolved to buy [155]. Furthermore, the level of personal participation in the decision-making process exposes the degree of risk perceived 
combined with the significance attributed to the choice of the object while allowing for the desires, interest, and personal values of the individuals $[156,157]$. Based on the perception of risk assigned in past works as the main inhibitor elements of various IS arena; similarly, it is expected to affect the acceptance of MFS negatively.

Taking the antecedent of MFS from a different angle, the importance of trust has been revealed to be an extensive subject matter. Trust, combined with the previous definitions so far, denotes the readiness of one party to be exposed to the actions of another party deal with the hope that the other will accomplish the designated task needed to the trustor [30]. The empirical findings of Jarvenpaa and Tractinsky [158] revealed the trust element to influence the decision to purchase in various manifold cultures. The prominence of trust is so decisive that it may be extended to be viewed as the "wild wild west" of the 21st century [136]. The more MFS users or potential users believe and trust the services, the more they can develop an affirmative goal for its usage. User trust, which has been revealed to be an important adoption facilitator in many IS environments, lacks adequate inspection in the context of MFS as a whole. In line with the literature allied with the antecedent of adoption of MFS in this study, we can, therefore, posit as follows:

Hypothesis 9. Disposition to trust would have a positive effect on an individual' espousal of MFS.

Hypothesis 10. User aggregate risk perceived would have a negative impact on the adoption of MFS.

Hypothesis 11. User general trust will positively influence an individual's acceptance to use MFS.

\subsection{Conceptual Framework}

To assess how trust and risk perceptions at the multidimensional level affect the mobile financial services (MFS) acceptance in Togo, we propose a research model. Figure 1 summarizes the relationships described in the research hypotheses. The proposed model is used to identify several attributes as predictors of MFS. Based on the above discussion related to the suggested hypotheses, we considered three antecedents (dispositional trust, technology trust, and vendor trust) as a multi-dimensional trust for the general trust, four antecedents (privacy risk, time risk, security risk, and cost) regarded as multi-facet perceived risk for the aggregate perceived risk. The remaining three antecedents (dispositional trust, perceived aggregate, and general trust) are used for consumers' intention toward the adoption of mobile financial services. Demographic variables entailing age and education levels are included in the model as control variables.

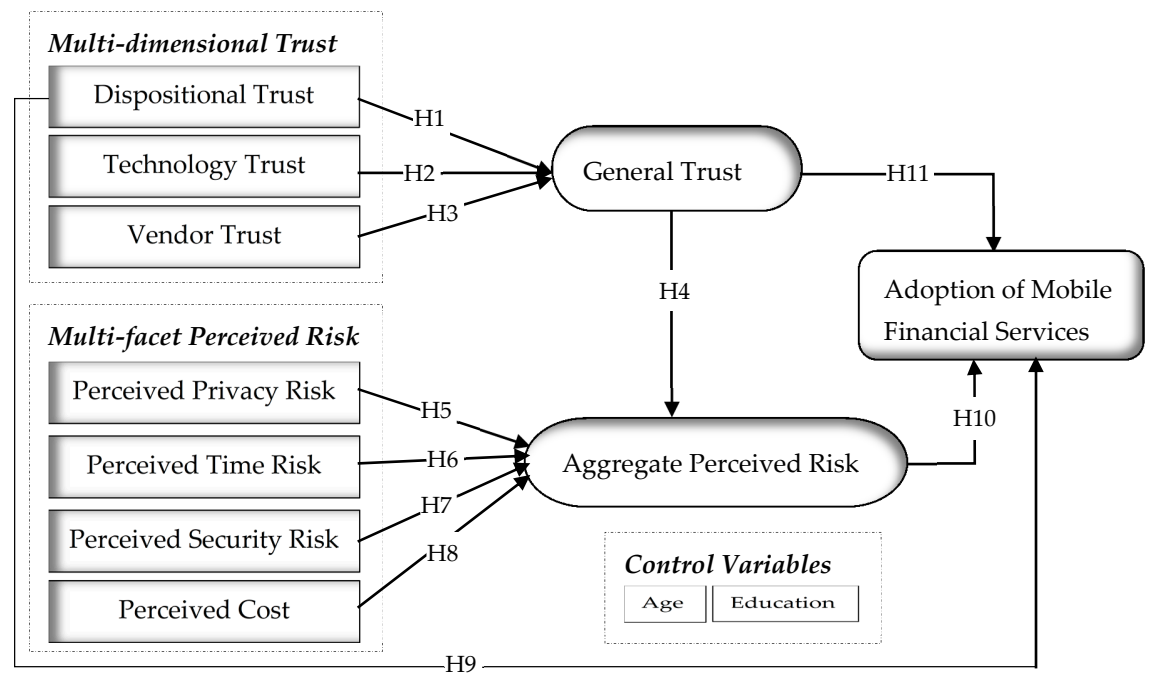

Figure 1. Proposed research model. 


\section{Research Methodology}

\subsection{Design and Data Collection}

Various schools of thought questioned how data collected would be executed as well as the content of the studies. Among them, Cooper and Schindler [159] have suggested two approaches of scrutinizing issues: One technique called observational approach is to gather data on people, event, situations, and behavior; while the next one, the so-called communication approach, has considered the attitudes, expectations intentions, and motivator aspect.

This research, as a result, used data collection via the communication approach, taking a form of the survey since the motive of the study turns to capture the influential factor of MFS adoption once testing the research model. A survey instrument was then established for indicators and criteria development, which primarily got ratified after revising the suitability of the constructs by the chosen experts of MFS. The preliminary draft of the questionnaire was prepared in English then translated into French (the official language of Togo) for its assessment as well. Both questionnaires in English and French have been retained as to avoid any confusion related to the scope, purpose, and content; so far, allowing the comparison of the versions for discrepancies concerns, steadfastness to be easily acknowledged and established. Following the advice and the opinion from the experts, redundant and confusing items were either improved or removed. As a result, new items were included in the questionnaire lastly, permitting the validity of the survey instrument employed. The research model embodies ten factors; each factor remains evaluated with multiple items. Also, all items were accommodated from existent literature to increase content validity [160]. There were two types of questionnaires. The first type (SEM questionnaire) was divided into two parts. The first part was distributed with bio-data of the sample, and the second part answered the MFS questions using the five-point Likert scale bounded from strongly disagree (1) to strongly agree (5). The final measurement scales, items, and their sources are listed in "Appendix A".

For the second type of questionnaire (TOPSIS questionnaire), we arbitrarily contacted users and potential users and questioned them whether they had mobile MFS usage experience to ensure their familiarity to some extent as recommended $[10,161]$. Thus, those with two or more MFS experience years were further invited to fill the TOPSIS questionnaire format.

The empirical study took almost three months of the span for data collection because of the delay in obtaining some participants' responses and an awkward time-period indicated by some of them. Data were collected at some of the busiest and most crowded places of the capital town Lomé (i.e., Assivito, Dekon, Be, and Université de Lomé) where potential users and currents users of mobile financial services (MFS) can relatively be found and inspected better than in other sectors. Literate people filled in their survey questionnaires themselves, whereas for illiterates, help was given. The questionnaire took almost 10-15 min to complete by a given participant. The estimated accessible population of Lomé is 837,437 [162]. Therefore, the estimated adjusted sample size for this research should have a minimum of $399.8090 \cong 400$ [163]. In the situation which involves minor participants, informed consent has been given by legal representatives together with the minor participants "assent" before partaking in a study. An exception to this procedure was when teenagers are employed and living on their own.

Once the data collection procedure was completed, we examined all questionnaires and discarded cases with too many missing and or rushed responses.

As such, 538 questionnaires, which fulfilled the minimum requirement, were both ready and yielded usable samples. Among them, 294 (54.6\%) were male and 244 (45.4\%) female. Seventy-five (13.9\%) respondents were aged below 18 years, 145 (27\%) aged between $19-24$ years, 199 (37\%) aged between 25-30 years, and 119 (22.1\%) aged above 31 years. Regarding educational qualifications, the majority of respondents (two hundred and sixty-seven) had a high school certificate or below, i.e., Baccalaureate (49.6\%), $203(37.7 \%)$ had a graduate degree, while $57(10.6 \%)$ had a master's degree. The remaining $11(2 \%)$ had a doctorate. Concerning MFS years of experiences, $187(34.8 \%)$ of respondents 
claimed to have no experience with MFS, 194 (36.1\%) used it for less than one year, $125(23.2 \%)$ MFS usage ranged from the 1-2 years, 26 (4.8\%) were found between 3-4 years of MFS experience. Only $6(1.1 \%)$ had MFS experience for more than five years. Hence, very few respondents had MFS experience above three years from the deduction. Moreover, they are those respondents engaged in MFS application at the early stage of its implementation (Most MFS companies in Togo started launching their activities in the year 2013) and dwell on it.

\subsection{Proposed Technique of Data Analysis: SEM-TOPSIS Methods}

The SEM-TOPSIS technique was employed to construct the MFS evaluation decision support system. Therefore, SEM was utilized to generate critical criteria and weights, whereas TOPSIS was used to engender the rank and score of alternatives as well permitted the fullness of the data, improved the data accuracy via group decision making.

SEM is suitable to estimate and test casual relationships by employing a combination of statistical data and qualitative assumptions $[15,164]$. It remains a second-generation multivariate technique that tolerates the simultaneous assessment of multiple equations, embraces multiple regression analysis, factor analysis, and path model analysis [165]. SEM incorporates the whole analysis of construct concurrently rather than separately [166], with this application being emergent in the social sciences [167]. Accordingly, it is the handiest method adapted for checking causative relations between predictors and adoption behavior [168,169]. It offers greater flexibility in matching a theoretical model with a data sample when compared with techniques like PCA and factor analysis [170].

TOPSIS: Technique for Order Preference by Similarity to Ideal Solution. The various process of TOPSIS will be explained in the analysis section.

\section{Data Analysis}

\subsection{Measurement and Hypotheses Testing with SEM Analysis}

We performed exploratory factor analysis (EFA) employing maximum likelihood estimation with Promax because of the large sample of data set $(n=538)$ and its intricacy related to the outcome's elucidation, which is trivial in resolving the correlated. The EFA reveals the output of KMO as 0.809 and Bartlet's test of sphericity to be significant at $\alpha=0.000$ with a Chi-square of $11,598.920$, indicating the relevance for performing exploratory factor analysis [171]. Besides, the communalities for each variable were sufficiently high (lowest was 0.343 , the majority were beyond 0.597 , and the greatest was 0.975 ), showing the evidence that these variables were effectively correlated for factor analysis. The ten-factor model obtained a total variance explained with more than $60 \%$ along with all extracted factors partaking eigenvalue beyond 1.0.

To continue assessing our quantitative model, we settled the subsequent analysis in two phases [167]: first, via confirmatory factor analysis (CFA), we appraised both reliability and discriminant validity of the ten constructs [172]. The outcomes will achieve validity unless the researchers employ constructs that diverge from another construct in a similar model [172]. From the second step, we valued the structural model then SEM for hypotheses testing. These last two steps are adopted from previous studies $[28,173]$. Hence, we estimated the reliability of each construct based on three indices, such as composite reliability (CR), average variance extracted (AVE), and Cronbach's alpha (CA). The suggested values for good measures were at least $0.70,0.50$, and 0.70 , respectively [174], (see Table 1). In patronage of convergent validity, the AVE found to be higher than 0.5 for all constructs, and all item factor loadings remain beyond the minimum threshold of 0.4 [175]. 
Table 1. Reliability and validity in confirmatory factor analysis (CFA).

\begin{tabular}{|c|c|c|c|c|c|c|c|c|c|c|c|c|c|c|}
\hline & CR & AVE & MSV & $\operatorname{MaxR}(\mathrm{H})$ & (1) & (2) & (3) & (4) & (5) & (6) & (7) & (8) & (9) & (10) \\
\hline (1) & 0.846 & 0.647 & 0.227 & 0.848 & 0.804 & & & & & & & & & \\
\hline (2) & 0.933 & 0.779 & 0.133 & 0.965 & 0.108 & 0.883 & & & & & & & & \\
\hline (3) & 0.904 & 0.704 & 0.087 & 0.975 & 0.216 & 0.067 & 0.839 & & & & & & & \\
\hline (4) & 0.860 & 0.609 & 0.057 & 0.979 & 0.168 & 0.157 & 0.155 & 0.780 & & & & & & \\
\hline (5) & 0.855 & 0.664 & 0.227 & 0.981 & 0.476 & 0.020 & 0.230 & 0.144 & 0.815 & & & & & \\
\hline (6) & 0.843 & 0.577 & 0.056 & 0.984 & 0.236 & 0.061 & 0.114 & 0.011 & 0.235 & 0.760 & & & & \\
\hline (7) & 0.856 & 0.600 & 0.133 & 0.985 & 0.041 & 0.365 & 0.044 & 0.238 & -0.022 & -0.072 & 0.775 & & & \\
\hline (8) & 0.811 & 0.594 & 0.065 & 0.987 & 0.127 & 0.155 & 0.113 & 0.232 & 0.091 & 0.035 & 0.255 & 0.771 & & \\
\hline (9) & 0.798 & 0.571 & 0.013 & 0.987 & 0.102 & 0.098 & 0.065 & -0.004 & -0.035 & 0.086 & 0.075 & 0.115 & 0.756 & \\
\hline (10) & 0.820 & 0.610 & 0.087 & 0.988 & 0.228 & 0.051 & 0.295 & 0.064 & 0.198 & 0.216 & -0.042 & 0.019 & 0.104 & 0.781 \\
\hline
\end{tabular}

Note: (1) DTrust: dispositional trust; (2) TTrust: technological trust; (3) Vtrust: vendor trust; (4) PPrivR: perceived privacy risk; (5) PTimeR: perceived time risk; (6) PSecurR: perceived security risk; (7) PCost: perceived cost; (8) PRisk: perceived risk; (9) AdMFS: adoption of MFS; (10) G-trust: general trust.

Moreover, all loadings of items arose in the corresponding construct, and no item loaded with the high value in another construct. This technique was espoused in past research [15,176,177]. As such, we established that our ten constructs displayed convergent validity (see Table 1 below).

We designed Table 2 to portray the goodness of fit of CFA and SEM. Apart from the goodness-of-fit index (GFI) for CFA slightly below the recommended, as this index is sensible to sample size, and in this study, we use large sample size $(n=538)$; for all indexes, our measurement model and structural model indicated sufficient goodness of fit.

Table 2. The goodness of fit (CFA and structural equation modeling (SEM)).

\begin{tabular}{ccccc}
\hline Indices & Abbreviation & CFA Value & SEM Value & Thresholds \\
\hline Chi square & $\mathrm{x}^{2}$ & 1068.904 & 30.445 & $p$ value $>0.05$ \\
\hline Normed chi square & $\mathrm{x}^{2} / \mathrm{DF}$ & 2.104 & 1.903 & $1<\mathrm{x}^{2} / \mathrm{df}<3$ \\
\hline Root mean square residual & $\mathrm{RMS}$ or RMR & 0.066 & 0.015 & $<0.08$ \\
\hline Goodness-of-fit index & GFI & 0.889 & 0.991 & $>0.90$ \\
\hline Adjusted GFI & AGFI & 0.862 & 0.955 & $>0.80$ \\
\hline Normed fit index & NFI & 0.900 & 0.941 & $>0.90$ \\
\hline Comparative fit index & CFI & 0.944 & 0.968 & $>0.93$ \\
\hline Tucker-Lewis index & TLI & 0.935 & 0.869 & $0<$ TLI $<1$ \\
\hline Root mean square error of approximation & RMSEA & 0.045 & 0.041 & $<0.05$ excellent fit \\
& & & & $<0.08$ good fit \\
\hline
\end{tabular}

Before the structural model, we conducted a common method bias. Since the data for the variable were led through a single method (survey), we performed a test to check if a common factor might have been impacted our outcomes. Hence, the test adopted was an unmeasured latent factor suggested by Podsakoff et al. [178] and Siemsen et al. [178] toward studies that do not obviously measure a common factor, mentioned as a common latent factor (CLF) method. The most prevailing and best method in checking the CMB is the zero-constrained test where the CLF is involved along with Marker if accessible [178]. This approach checks whether the shared variance across all variables differs significantly from zero. In a case it is, then there are bias issues. To proceed, we computed the chi-square difference test among the unconstrained model and the model per all paths regarding the CLF constrained to be zero. Since the result is markedly different from zero, we can conclude that method bias does occur in our measures. Thus, moving to the causal model based on the result, CLF was retained for our structural model (by imputing composites in AMOS in the presence of CLF), which provided CMB-adjusted values. 
We also check for invariance (configurable and metric) because of the presence of two groups, such as gender included in our data to see whether the factor and loading are adequately equivalent across groups. Davidov [179] has claimed that the assessment of path coefficients could only be useful if the invariance test has been done beforehand. The result signpost that the model fit of the unconstrained measurement models (per groups loaded distinctly) presented a sufficient fit $(\chi 2 / \mathrm{DF}=1.623, \mathrm{TLI}=0.928$, $\mathrm{CFI}=0.938$, RMSEA $=0.034$ ) when assessing a freely estimated model across genders. Grounded on the result, the model is configurally invariant. Once the model was constrained to be equal, the result of the chi-square difference test reveals the $p$-value $(0.226)$ to be nonsignificant. So, the measurement model satisfies the benchmarks criteria for metric invariance across gender as well. Then and there, we move on making the composite from this measurement model to build SEM for verification of hypotheses testing. The results of the structured model, together with parameters, were obtained while controlling for age and education. The standardized path coefficients, path significances, and explained variance $R^{2}$ of the structural model (see Figure 2).

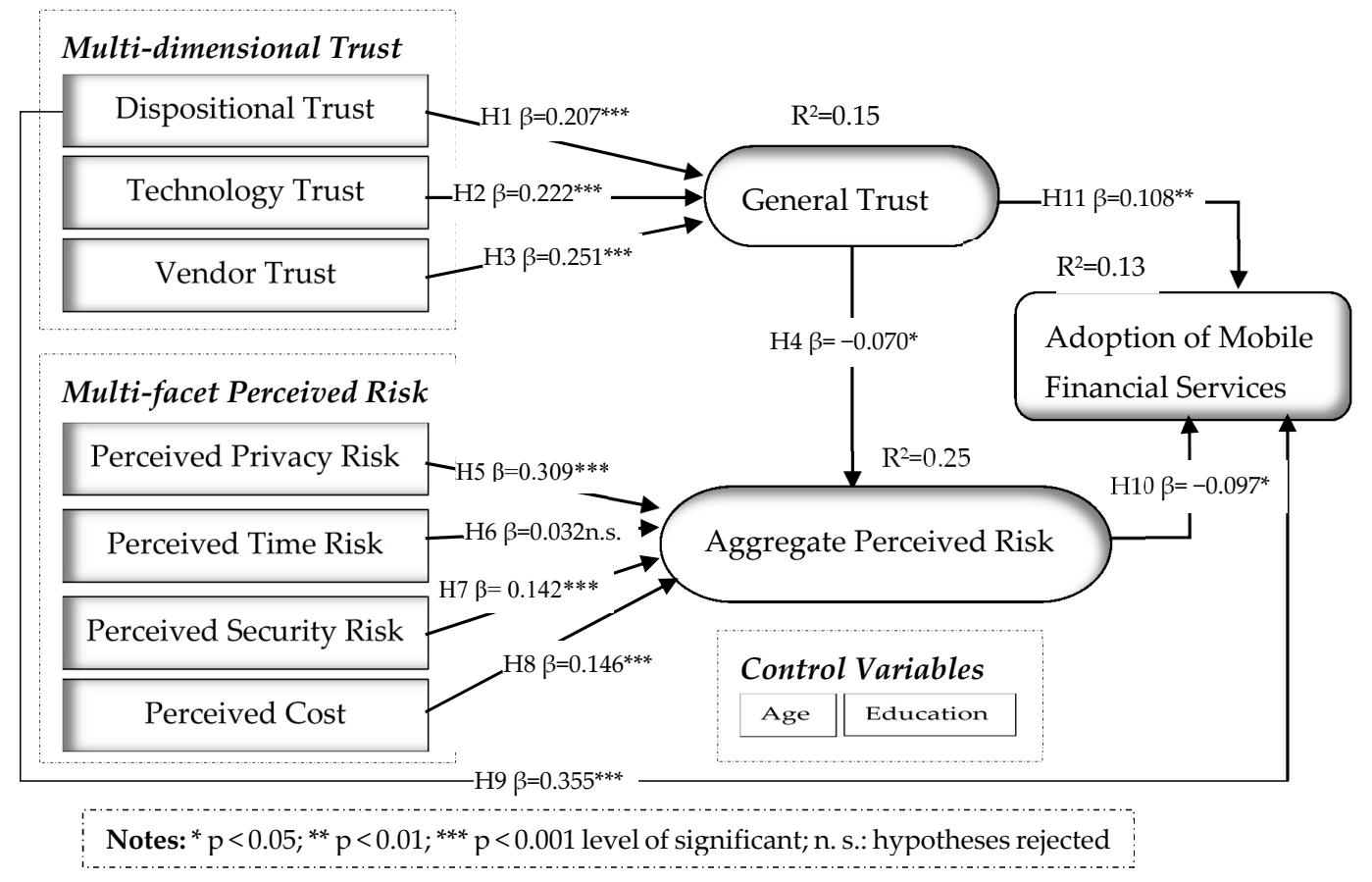

Figure 2. Final model after validation.

\subsection{TOPSIS Analysis}

The technique for order preference by similarity to ideal solution (TOPSIS) is a multiple criteria decision-making (MCDM) technique developed by Hwang and Yoon [180]. It is grounded in the criteria that the alternative should have the shortest distance from the positive ideal solution and the farthest from the negative ideal solution [181]. It has been extensively employed by researchers for the ranking of alternatives centered on different criteria [7,161,164,182,183]. When compared to other MCDM methods, TOPSIS necessitates limited subjective inputs from decision-makers [184] and remains a deterministic technique. It provides solution on both positive and negative way, which is beneficial for applications where there are considerations such as cost and benefits; and it is a rational method which works agreeably across various application areas [185]. Recall that the process of the SEM-TOPSIS can be characterized as follows. Primarily, SEM was applied to compute the hierarchical criteria and their relatives to ensure their significance. This is the reason why having the relative weightage obtained from SEM is reflected more valid than via any other method. The antecedent of trust and perceived risk given by the SEM model were deliberated for the relative weightage of the sub-criteria. 
The computation of TOPSIS methods grounded on Hwang and Yoon [180], Lin and Tsai [186], and predominantly the one required for grouping decision Shih et al. [187] were adopted and presented as followed:

Step 1: construction of decision matrix $\mathrm{D}^{\mathrm{k}}, k=1, \ldots, K$ for each DM. The matrix structure can be viewed below:

$$
\begin{aligned}
& n \text { Criteria } \\
& \begin{array}{llllll}
X_{1} & X_{2} & \ldots & X_{\mathrm{J}} & \ldots & X_{n}
\end{array} \\
& \mathrm{D}^{\mathrm{k}}=\quad \begin{array}{ccccccc}
A 1 \\
A 2 \\
\vdots \\
A \mathrm{i} \\
\vdots \\
A \mathrm{~m}
\end{array}\left[\begin{array}{cccccc}
\mathrm{x}_{11}^{\mathrm{k}} & \mathrm{x}_{12}^{\mathrm{k}} & \ldots & \mathrm{x}_{1 \mathrm{j}}^{\mathrm{k}} & \ldots & \mathrm{x}_{1 \mathrm{n}}^{\mathrm{k}} \\
\mathrm{x}_{21}^{\mathrm{k}} & \mathrm{x}_{22}^{\mathrm{k}} & \ldots & \mathrm{x}_{2 \mathrm{j}}^{\mathrm{k}} & \ldots & \mathrm{x}_{2 \mathrm{n}}^{\mathrm{k}} \\
\vdots & \vdots & \ldots & \vdots & \ldots & \vdots \\
\mathrm{x}_{i 1}^{\mathrm{k}} & \mathrm{x}_{i 2}^{\mathrm{k}} & \ldots & \mathrm{x}_{\mathrm{ij}}^{\mathrm{k}} & \ldots & \mathrm{x}_{\mathrm{in}}^{\mathrm{k}} \\
\vdots & \vdots & \ldots & \vdots & \ldots & \vdots \\
\mathrm{x}_{\mathrm{m} 1}^{\mathrm{k}} & \mathrm{x}_{\mathrm{m} 2}^{\mathrm{k}} & \ldots & \mathrm{x}_{\mathrm{mj}}^{\mathrm{k}} & \ldots & \mathrm{x}_{\mathrm{mn}}^{\mathrm{k}}
\end{array}\right]
\end{aligned}
$$

where $A_{i}$ refers to the likely alternatives of the decision process $i$ with $i=1, \ldots, m ; X_{j}$ denoting the attribute or criterion $j, j=1, \ldots, n$; with both quantitative and qualitative data. The value $x_{i j}^{k}$ remains, therefore, the performance score of alternative $A_{i}$ in relation to attribute $X_{j}$ by decision-maker $k, k=1, \ldots, K$, while $x_{i j}^{k}$ is the element of $\mathrm{D}^{\mathrm{k}}$. It is of importance to mention that there should be $K$ decision-maker matrices designed for $K$ participants of the group.

Step 2: the normalized decision matrix $\mathrm{R}^{k}, k=1, \ldots, K$ is generated for each $D M$. Vis-à-vis to any $D M k$, the vector normalization technique is used for computing the element $r_{i j}^{k}$ from the decision matrix $\mathrm{R}^{\mathrm{k}}$ which can take any linear-scale transformation to preserve $0 \leq r_{i j}^{k} \leq 1$ inequality. Since we consider the vector normalization operation, then $r_{i j}^{k}$ is given as:

$$
r_{i j}^{k}=\frac{x_{i j}^{k}}{\sqrt{\sum_{\mathrm{j}=1}^{\mathrm{n}}\left(\mathrm{x}_{\mathrm{ij}}^{\mathrm{k}}\right)^{2}}},
$$

where $i=1,2, \ldots, m ; j=1,2, \ldots, n$; and $k=1,2, \ldots, K$. It is also necessary to clue that the vector normalization method makes provision as to which one represents a cost criterion for additional management. Moreover, there is no need to directly assess the weighted normalized as per the case of the original TOPSIS [188].

Step 3. The positive ideal solution $V^{k+}$ (PIS), is made of all the best performance scores and the negative-ideal solution $V^{k-}$ (NIS) is made of all the worst performance scores at the measures in the weighted normalized decision matrix for each DM $k=1, \ldots, K$. For any given $D M k$, his/her PIS and NIS can be characterized in the form of

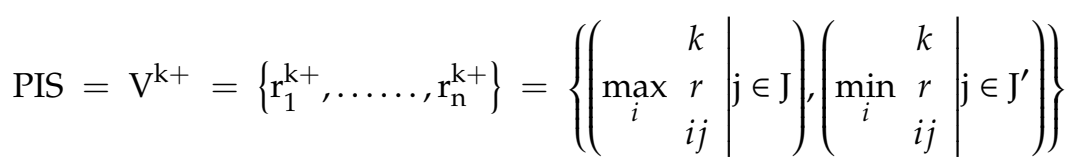

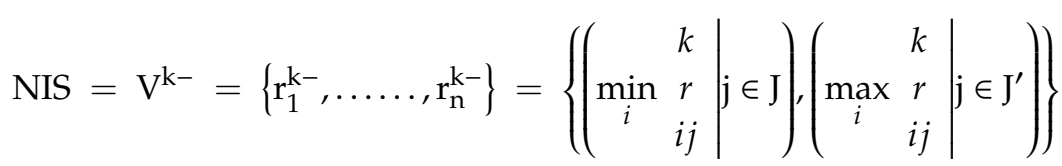

where $J$ is related to the benefit criteria and $J^{\prime}$ allied with the cost criteria, $i=1, \ldots, m ; j=1, \ldots, n$; and $k=1, \ldots, K$.

Step 4. A weigh vector $W$ is allocated to the attribute set for the group. Each DM will produce weights for attributes as $w_{j}^{k}$ where $j=1, \ldots, n$ and $\sum_{\mathrm{j}=1}^{\mathrm{n}} w_{j}^{k}=1$; and for each DM $k=1, \ldots, \mathrm{K}$. 
Each element of the weigh vector $\mathrm{W}$ will result from the operation of the corresponding components of the attributes' weights for every DM.

Step 5. Evaluate the separation measure through the positive ideal and the negative ideal solutions, $\overline{S_{I}^{+}}$and $\overline{S_{I}^{-}}$, relatively to the group. Because of the group decision with respect to this research, this step requires two sub-steps, where the initial one considers the distance measure for individuals while the next one aggregates the measure for the group.

Step 5a. Assessment of the measure from PIS and NIS individually. The n-dimensional Euclidean distance can compute the distance of an alternative $j$ to the ideal solution. Separation of each alternative from the positive ideal solution $S_{i}^{k+}$ is then provided by the Equation (5) below:

$$
\mathrm{S}_{\mathrm{i}}^{\mathrm{k}+}=\sqrt{\sum_{j=1}^{\mathrm{n}} w_{j}^{k}\left(v_{i j}^{k}-v_{j}^{k+}\right)^{2}}, \text { for alternative } i, i=1, \ldots, m
$$

Similarly, separation from the negative ideal solution $S_{i}^{k-}$ is then given by

$$
\mathrm{S}_{\mathrm{i}}^{\mathrm{k}-}=\sqrt{\sum_{j=1}^{\mathrm{n}} w_{j}^{k}\left(v_{i j}^{k}-v_{j}^{k-}\right)^{2}}, \text { for alternative } i, i=1, \ldots, m .
$$

Step 5 b. Assessment of the measure from PIS and NIS for the group. In this part, the individual group measure of each alternative is to be integrated via an operation $\otimes$ for all DMs, $k=1, \ldots, K$. As such, the two-fold measure of the PIS and NIS are presented below

$$
\begin{aligned}
& \overline{S_{i}^{+}}=\overline{S_{i}^{1+}} \otimes \cdots \otimes \overline{S_{i}^{K+}}, \text { for alternative } i, \\
& \overline{S_{i}^{-}}=\overline{S_{i}^{1-}} \otimes \cdots \otimes \overline{S_{i}^{K-}}, \text { for alternative } i .
\end{aligned}
$$

Though this operation can provide various choices like geometric mean, arithmetic means with their related extended; this study pondered only on the geometric one for the group computation. Its calculation's formulae are below shown for PIS and NIS (Equations (9) and (10))

$$
\begin{aligned}
& \overline{S_{i}^{+}}=\left(\prod_{k=1}^{K} S_{i}^{k+}\right)^{\frac{1}{K}}, \text { for alternative } i \\
& \overline{S_{i}^{-}}=\left(\prod_{k=1}^{K} S_{i}^{k-}\right)^{\frac{1}{R}}, \text { for alternative } i .
\end{aligned}
$$

where $i=1, \ldots, m ; k=1, \ldots, K$.

Step 6: The ranking score $\overline{C_{i}^{*}}$ is computed as

$$
\overline{C_{I}^{*}}=\frac{\overline{S_{i}^{-}}}{S_{i}^{+}+S_{i}^{-}}, i=1, \ldots, m
$$

With $0 \leq \overline{C_{I}^{*}} \leq 1$. When $C_{I}^{*}$ is close to 1 , the alternative is considered as ideal; and when $C_{I}^{*}$ is close to 0 , the alternative is considered as non-ideal. The larger the index values, the higher the rank order, and so, the better the alternative' performance.

\subsection{Case Study Using Combined SEM-TOPSIS Techniques}

To establish the applicability of the suggested methodology (SEM-TOPSIS), a case study is carried out in this paper. The data examined were provided by respondents (74 MFS experienced 
users and experts) of mobile financial services, particularly for adopting the TOPSIS technique. The relative weightage is computed from the standardized total effect, normalized obtained from the SEM technique [10,189], and presented in Table 3. The weightings showed the importance of each sub-criteria for the MFS companies.

Table 3. Relative weightage of sub-criteria.

\begin{tabular}{ccccccc}
\hline DTrust & TTrust & VTrust & PPrivR & PTimeR & PSecurR & PCost \\
\hline 0.265 & 0.128 & 0.177 & 0.200 & 0.021 & 0.109 & 0.101 \\
\hline
\end{tabular}

Note: (1) DTrust: dispositional trust; (2) TTrust: technological trust; (3) Vtrust: vendor trust; (4) PPrivR: perceived privacy risk; (5) PTimeR: perceived time risk; (6) PSecurR: perceived security risk; (7) PCost: perceived cost.

To compute the relative weightage of MFS alternatives to each sub-criteria toward the criteria (trust and risk), the decision matrix of alternative performance evaluation (Equation (1) step 1) was created. Moreover, the output of the qualitative attribute from each alternative can also be set as discrete value or linguistic values (referring to Table 4) intentionally that the quantitative values could be set in the decision matrix above. Participants were asked to provide a set of values within the range of one to nine for the sub-criteria using Table 4 as measurement scale.

Table 4. Transformation of linguistic scale into quantitative values.

\begin{tabular}{ccc}
\hline \multirow{2}{*}{ Linguistic Scale } & \multicolumn{2}{c}{ Quantitative Values } \\
\cline { 2 - 3 } & Benefit-Max & Cost-Min \\
\hline Very High & 9 & 1 \\
\hline High & 7 & 3 \\
\hline Average & 5 & 7 \\
\hline Low & 3 & 9 \\
\hline Very Low & 1 &
\end{tabular}

Following the procedure of the TOPSIS method, through a TOPSIS algorithm built-in MATLAB technical computing tool, the relative weightage of MFS allied with each sub-criterion is calculated and shown in Table 5. After aggregating the individual PIS and NIS via geometric mean from the Step $5 \mathrm{~b}$ Equations (7) and (8), then the final score $\overline{C_{I}^{*}}$ is computed using Equation (11) of Step 6, followed by the ranking of the MFS alternatives as being portrayed in Figure 3 and Table 6.

Table 5. Summary of the relative weightage of mobile financial services (MFS) to each sub-criterion.

\begin{tabular}{cccccccc}
\hline \multicolumn{7}{c}{ Relative Weightage of MFS to Each Sub-Criterion } \\
\hline Sub-criteria weightage & 0.265 & 0.128 & 0.177 & 0.200 & 0.021 & 0.109 & 0.101 \\
\hline Sub-criteria & DTrust & TTrust & VTrust & PPrivR & PTimeR & PSecurR & PCost \\
\hline MB & 5.40 & 4.78 & 6.23 & -3.56 & -7.53 & -4.20 & -6.50 \\
\hline MP & 8.50 & 5.40 & 4.43 & -2.34 & -8.20 & -5.00 & -7.00 \\
\hline MMT & 7.30 & 4.70 & 5.11 & -1.42 & -8.00 & -4.48 & -7.20 \\
\hline
\end{tabular}

Note: MB: mobile banking; MP: mobile payment; MMT: mobile money transfer. 


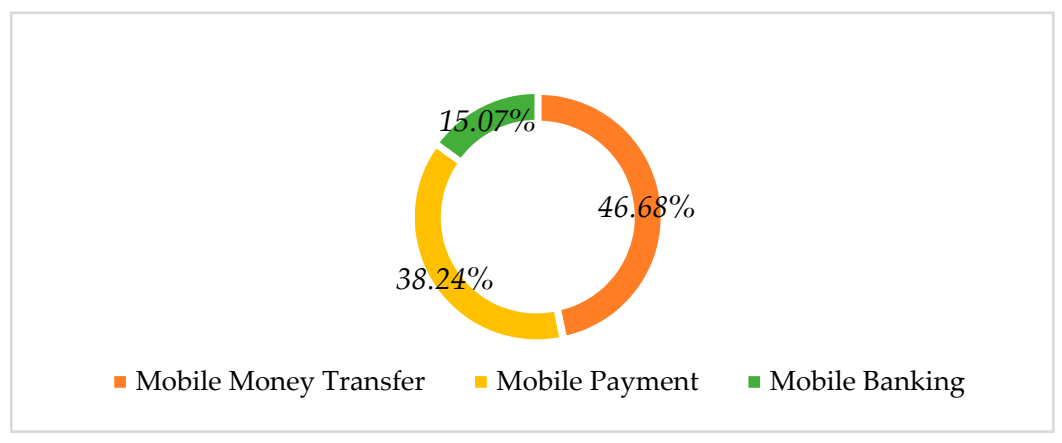

Figure 3. Classification of MFS alternatives using TOPSIS (\% representation).

Table 6. Results of three alternatives of MFS ranking using TOPSIS.

\begin{tabular}{cccc}
\hline MFS & $\overline{C_{I}^{*}}$ & Rank & \% Distribution of Coefficient \\
\hline MMT & 0.7454 & 1 & $46.68 \%$ \\
\hline MP & 0.6106 & 2 & $38.24 \%$ \\
\hline MB & 0.2407 & 3 & $15.07 \%$ \\
\hline
\end{tabular}

\section{Discussion}

New technology adoptions are impacted mainly by many factors, which may vary from technology concerns to the trust dimension, the perception of risk facets, and the behavior of users, to mention a few. The intricacy and significance related to the effort in elucidating the motives or reasons for users' adoption or rejection of new IT have led to the development of various concepts. Furthermore, there are a plethora of studies on the influence of trust and perceived risk with their determinant toward the adoption decision in an online environment.

Conversely to prior research works, this study scrutinizes the influence of critical variables such as multi-dimensional trust and perceived risk facets on the consumers' adoption behavior of MFS and incorporates each of them into the MFS alternative decision-making scenario. Some postulations were made toward the possible relationship among the factors. The findings are yet to be probed purposively to draw an important conclusion and implication. The result of the MFS structural model analysis regarded as a final model after validation is summarized and portrayed in Figure 2. To be specific, the discussion section is scheduled to be under two sections. The first section will be made with SEM methodology grounded on hypotheses results, which are comprised of three sets. First set: hypotheses associated with trust; second set: hypotheses associated with perceived risk; and third set: hypotheses associated with MFS adoption constructs. The last section of the discussion is booked for a succinct analysis of TOPSIS output obtained via the SEM-TOPSIS hybrid technique.

It should be mentioned that all hypotheses were tested when controlling for age and education. The reason for controlling variables is to support mitigating the unrelated effect. Moreover, its use contributes to improving the robustness and validity of the outcome. In terms of relationships, the study account for the $p$-value column allied with each variable where the related $p$-value of less than 0.05 indicates a significant relation associated. The results of the entire tested eleven hypotheses were statistically significant except for the relationship between perceived time risk (PTimeR) and perceived risk (PRisk, i.e., $\mathrm{H} 6$ as displayed from Figure 2).

The first set of hypotheses is related to trust, which was scrutinized by H1-H3. Empirical evidence is found to accept hypothesis $\mathrm{H} 1(\beta=0.207, p<0.001)$, which refers to the positive effect the disposition to trust has on general trust in MFS. Payne and Clark [190] showed that the general disposition to trust exerts substantial control on the trust among senior managers in an industrial context. Moreover, consumers' disposition to trust has been revealed to maintain a strong influence on their trust in an e-vendor. Although most of the previous studies did not plainly define the direction of 
the impact, the present study ratifies that disposition to trust and trust are positively related in MFS. Such information comes to back the knowledge that consumers who unveil a greater disposition to trust will more willingly trust the e-vendor [137] compared to those who will require more info [191]. However, our results are contradicted by earlier e-services [110], particularly in mobile banking. The reason might be that when consumers are to encounter a choice within MFS perspectives (mobile banking, mobile payment, mobile money), their trust disposition significantly affects the general trust more or less that of the single type of MFS. As a result, companies dealing with MFS should be aware of this critical effect and prepare for any competitive advantage strategies in the marketplace.

$\mathrm{H} 2$ ( $\beta=0.222, p<0.001$ ) tested the effect of trust in technology on trust in general, and the findings stressed that technology trust has a strong positive impact on trust. Given technological trust as a sole antecedent of trust whereby the object upon which the trust remained imparted when referring to the inert technology [192], then, our empirical results are in line with previous findings in the context of mobile banking [110]. Furthermore, previous works [193] implicitly incorporated the concept of trust technology to trust with its importance being emphasized as a facilitator of e-commerce adoption.

Trust in the vendor was also found to have a positive influence on general trust, which supports H3 ( $\beta=0.251, p<0.001)$. The results of this research are reliable with the previous finding in which vendor trust has been defined as multi-dimensional and influential levers that the vendors could employ to build consumer trust [113]. Vendor trust remains so vital to promoting trust in changing a potential consumer from a curious viewer to one that will be ready to perform MFS. Thoughtful discerning of the essence and antecedents of consumer trust in MFS can support e-vendors with a set of controllable, strategic levers to develop such trust, which will encourage greater MFS acceptance and usage.

As a result, lack of consumer trust (trust disposition, technology trust, and vendor trust) in the overall online environment has been, and persists in being, a hamper to IS adoption [194] and thus to MFS. All these could serve as a clue to the concept that the consumers' espousal of MFS may be shaped accordingly.

The second set of hypotheses is associated with perceived risk. From this part, perceived risk has five antecedents, such as $\mathrm{H} 4$ and $\mathrm{H} 5-\mathrm{H} 8$. The investigation of the relationship between trust and perceived risk has been one of the main issues in the development of IS [195]. Our result shows that general trust has a negative influence on perceived risk, which supports $\mathrm{H} 4(\beta=-0.070, p<0.05)$. The literature offers supportive studies on the import of this relationship [8,195]. Various researchers have also contributed to the belief that trust mitigates consumers' perceived risk [196-198] as well as affecting perceived benefit in e-commerce [199]. Lots of incentives that increase trust are similar incentives that reduce perceived risk. This result clarifies to some extent, the doubt related to the direction of the causality between trust and risk, which were found deficient from the past literature [121]. From $\mathrm{H} 5-\mathrm{H} 8$, the empirical study found to patronize all the hypotheses at a different level of $p$-value mention that each dimension of perceived risk has a positive influence on the overall perceived risk except $\mathrm{H} 6$ (see Figure 2). At that point, the moderate to weak positive relationships between the perceived risk (aggregate) and the risk component offers further reinforcement that risk can be researched as a multidimensional phenomenon [200]. These results are also consistent with the work of Featherman and Pavlou [127], which validated a majority of these antecedents as a risk dimension; therefore, being the influential element of the aggregated risk. Again, the outcomes reveal the multidimensional nature of perceived risk in information technology, mainly MFS. Boksberger et al. [201] are supporters of these findings in the area of air travel. Again, the results show that perceived privacy risk H5 ( $\beta=0.309$, $p<0.001)$ is indeed the predominant perceived risk dimension for the partakers of MFS, shadowed by the perceived cost $\mathrm{H} 8(\beta=0.146, p<0.001)$ and perceived security risk $\mathrm{H} 7(\beta=0.142, p<0.001)$. Moreover, this study confirms the positive effect of the perceived cost on the consumers' perceived risk, such as that the lower the cost, the more minor the perception of risk and the more the likelihood of MFS adoption. As such, the involvement aspect of the risk [202] is importantly observed when the price or cost is high, and the consumers risk losing money. 
This research reveals no statistical evidence to support the hypothesis H6 ( $\beta=0.032, p<0.342)$ that perceived time risk has a positive influence on the aggregate perceived. Although $\mathrm{H} 6$ is rejected; the expected direction of the relationship is kept just so that the $p$-value is not statistically significant at 0.05 . However, our findings are controverted by prior online payment research that has indicated a positive relationship between time risk and perceived risk [203]. It has stressed that consumers lack patience in waiting a long time because they are always delighted in pursuing new things [203]. Then, a longer waiting time for service delivery would deter the desire, impact their buying disposition or decision to adopt as well. In the view of this current study, the perceived risk dimension, such as perceived time risk, does not appear to impact the specific information technology acceptance, at least for the Togolese MFS investigated in this research. The reason may be related to the participants' (user and potential user) MFS experience. Since quite many of them lack experience in MFS, they might not be conscious regarding the real time needed for a service to be completed. This implies that the effect of time risk perceived is worthy of further development in future researches and MFS companies are encouraged to continue easing the transaction process of MFS in terms of time spent.

The third set of hypotheses is associated with the adoption of MFS. Among them, the hypothesis associated with the positive relationship that the dispositional trust has with MFS adoption was supported by the test result; hence, H9 $(\beta=0.355, p<0.001)$ is accepted (Figure 2$)$. This infers that when increasing the level of trust disposition, individuals tend to adopt MFS technologies without necessarily cogitating on the general trust. The finding is consistent with e-commerce adoption for SMEs [204]. Moreover, the scholars reported that indicators for the dispositional trust should be incorporated into empirical studies either as a moderating variable or as a precursor of trusting beliefs, intentions, and behaviors [205]. Being an antecedent of trust, a disposition to trust remains one of the most operative elements required during the launch phases of a relationship when parties are generally unacquainted with each other [206]. Given that MFS is still in the early stages of adoption in Togo, services providers are recommended to promote the variable that could increase the consumer's dispositional trust.

From Figure 3, perceived risk significantly negates the adoption and usage of MFS, rendering the support of H10 ( $\beta=-0.097, p<0.022)$. It is so crucial to signpost the feasibility of this outcome to be enlightened by the theory of consumer behavior [116] allied with risk perception. The importance of perceived risk in the study also confirms previous studies that demonstrate that consumers' perceived risk is more efficacious at clarifying purchasing or adoption behavior inasmuch as consumers are more recurrently driven to avert mistakes than to capitalize on utility in purchasing [207]. This output is also coherent with a recent report on mobile payment adoption, which underlines rapid technology innovation while stressing the importance of perceived risk in the form of security $[208,209]$.

Last but not least, the study entails and accepts the hypothesis H11 $(\beta=0.108, p<0.008)$ in which general trust has a positive influence on MFS adoption. Generally, trust remains a vital factor in various economic and social relations involving uncertainty and reliance [210,211], particularly those regarding important decisions [212] and new technologies [198] as an MFS perspective. Accordingly, our findings are sustained via the idea that trust in business rests on the pertinent and crucial stimulus of behavior in general [213-215], and the facilitator factors for MFS adoption and usage in particular.

Under this set, it can then be deduced that both improving trust and decreasing risk continue to raise the likelihood level of consumers' engagement in MFS transaction. Companies are required to take the necessary precaution to balance the trade-off.

SEM-TOPSIS: It is noteworthy to recall that the second section of discussion concerns the output of MFS alternatives computation. The overall result from the TOPSIS technique shows the preference of each alternative regarding the various sub-criteria. The relative closeness $\overline{C_{I}^{*}}$ results obtained satisfies the sine qua non-condition, i.e., $0 \leq \overline{C_{I}^{*}} \leq 1$. Furthermore, TOPSIS technique is grounded on the principle that the higher the value of $\overline{C_{I}^{*}}$, the high the rank order, and consequently, the more the chosen alternatives are favored over others. The final result reveals that mobile money transfer (MMT) is the most preferable MFS to adopt and use with $\overline{C_{I}^{*}}$ tantamount to 0.7454 signifying $46.68 \%$ compared to 
the last two remainings. Mobile payment (MP) with 0.6106 (38.24\%) was found to be the second MFS alternative used, whereas mobile banking (MB) adoption with 0.2407 (15.07\%) is considered minor. This finding is relatively supported by the prior study on mobile banking and mobile payment, where $82 \%$ of participants under 35 years old have made mobile payments as compared to $79 \%$ who used mobile banking [216]. A similar past study has further shown that mobile payment usage among USA millennials was higher than that of mobile banking generally. The likely motive of the MFS preference acknowledged in this study can be explained based on the significant issues of concern toward perceived privacy risk. Using mobile money transfer or mobile payment service does not necessarily involve consumers' personal information or an account that needs to be connected to a bank account. By that, lots of end-users would rather opt for mobile money transfer and mobile payment than for mobile banking accordingly.

Table 7 below compares the outputs of TOPSIS and AHP and reveals the same results for the choice of the alternative ranking of mobile financial services (MFS). It was found that the outcomes were well consistent and, in general, agreed with each other. Based on the results of the ranking of the two techniques, mobile money transfer (MMT) was chosen as the most appropriate among the mobile financial services followed by mobile payment and mobile banking. However, there are slight differences found in the percentage of coefficient distribution among the classification of their alternatives. For instance, AHP reveals that MFS consumers have a high preference in using mobile money services (i.e., the difference in the percentage of coefficient: $13.32 \%$ ) as compared to TOPSIS results. Contrarily, the TOPSIS result shows that consumers are more interested in using mobile payment when considering the difference in percentage sharing between the two techniques (i.e., the difference in the percentage of coefficient: $13.75 \%$ ).

Table 7. Comparison between TOPSIS and analytic hierarchy process (AHP) outputs.

\begin{tabular}{cccccc}
\hline $\begin{array}{c}\text { MFS } \\
\text { Alternatives }\end{array}$ & $\begin{array}{c}\text { TOPSIS \% Distribution } \\
\text { of Coefficient }\end{array}$ & TOPSIS Rank & $\begin{array}{c}\text { AHP \% Distribution of } \\
\text { Coefficient }\end{array}$ & AHP Rank & $\begin{array}{c}\text { The Difference in the \% } \\
\text { Distribution Coefficient }\end{array}$ \\
\hline MMT & $46.68 \%$ & 1 & $60 \%$ & 1 & $13.32 \%$ \\
\hline MP & $38.24 \%$ & 2 & $24.49 \%$ & 2 & 13.75 \\
\hline MB & $15.07 \%$ & 3 & $15.26 \%$ & 3 & $0.19 \%$ \\
\hline
\end{tabular}

Note: The outputs of AHP are derived from the previous work of Gbongli [10].

However, the results regarding the difference in percentage distribution of coefficient between TOPSIS and AHP in terms of mobile banking selection remain trivial. These results stressed that MFS consumers would not prefer using mobile banking if they have a choice between the proposed mobile financial services (MFS).

The difference between the finding of TOPSIS and AHP in the choice of MFS depends on their strengths and weaknesses, which are thoroughly pronounced in the literature $[161,217]$. For instance, the core advantages of AHP over TOPSIS can be attributed to its intuitive appeal to decision-makers, and its ability to check inconsistencies. Furthermore, decision-makers find the pairwise comparison system of data input convenient and straightforward. However, the application of AHP leads to the decision problem being decomposed into numerous subsystems, which require a considerable number of pairwise comparisons to be completed. Therefore, it is a complex and time-consuming implementation. In the situation of TOPSIS, the non-linear relations between one-dimensional scores and distance ratios lead to the consideration of both negative and positive ideal solutions. Also, in the TOPSIS framework, we can use variables with different units of measurement. It is very simple and easy to implement so that it is adopted when the user prefers a simpler weighting approach. However, TOPSIS, in its standard and original form, is deterministic and does not embrace uncertainty in the calculations associated with final weightings. 


\section{Conclusions}

The objective of this study was to examine the influence of both multidimensional trust and perceived risk facets at the individual level concurrently on the acceptance of mobile financial services (MFS) when prioritizing the MFS perspective. This paper's goal is to illuminate, to some extent, the MFS accessibility in Togo allied with the potential facilitators or inhibitor factors. Also, to evaluate them based on the consumer's experience and experts through a benchmark robust SEM-TOPSIS methodology. A qualitative study in the context of the Togolese was performed together with a literature review to derive the most probable factors that might influence end-users' perception of MFS since there was a scarcity of research investigating general trust and perceived risk antecedents. A quantitative study was then propelled to test the hypotheses formulated through the collected information obtained.

Our research model efficaciously integrates these dimensions, such as trust (dispositional trust, technological trust, and vendor trust), perceived risk (privacy, time, security, and cost) viewed as complex multidimensional factors. The data support the underlying assumption of the study except for H6 (see Figure 2). Mainly, our study is partially similar to the recent study done in Ghana (neighboring country of Togo) in which the perceived risk found to be related to the customer's trust in service providers regarding the adoption of mobile money [218]. In this line, our study provides more information to the various role-players of MFS about the necessity to emphasize on the trust and risk at the multidimensional level while making strategic and multicriteria decision-making.

Among the MFS alternative, the ranking result revealed mobile money to be the preferable MFS type used, followed by mobile payment and mobile banking with a minor percentage. When the ranking of TOPSIS was compared with those obtained by the AHP techniques in a similar given population, the findings were well consistent and, in general, approved with each other. However, a slight difference was found between both techniques and therefore placing TOPSIS better suited to the problem of MFS classification for the study area.

\section{Implication}

\subsection{Implication for Practice}

The outcomes of this study expose and validate the factors that impact consumers' adoption of MFS. First, the relative level of the path coefficients in our analysis model recommended that disposition to trust (an antecedent of trust) be the most salient factor that facilitates either directly or indirectly the adoption of MFS. The perceived privacy risk (an antecedent of perceived risk) as the next influential factor, however, hinders MFS adoption. Given this trusting disposition is developed throughout a lifetime [206] and reveals social impact over broad periods [198], it implies that there might be a presence of a cross-cultural difference in trust. If so, MFS companies' providers must expect various levels of trust, and thus, different proportions of MFS adoption as well. As a deduction, companies are recommended to be acquainted with building trust-based tools and for instance, increasing awareness and firms' reputations by keeping their promises while treating the customer as individuals, mainly in societies that acknowledge exhibiting a lower level of trust. MFS service providers could meritoriously upsurge adoption behavior by publicizing the advantages of MFS to potential consumers, seeing that the findings supported trust with all of its antecedents.

Moreover, by modeling perceived risk with various facets, this study's finding imparts numerous risk effect concerns. From this perspective, when companies propagandize their MFS services to ease the adoption issues, they should realistically underline a neutralizer or counter step for those risks' perceptions. The prominence of privacy risk and financial risk in the form of perceived cost as confirmed by this study and others prior research [219] signposts that customers still have doubts about the security of virtual transactions. For instance, these companies may stimulate a privacy risk protection strategy and grant technological support and anti-fraud to guarantee potential end-users minimal security risk. It is typical in the practice of emerging and developed countries (and it should 
be considered in developing countries as well) for payment service providers to try and promote trust in mobile financial services, in payments in general, as well as in other banking services by improving the general financial literacy of the population and small and medium enterprises. This is important, as those individuals who are familiar with financial processes and concepts demonstrate more trust toward financial services and can assess their risks better [220]. An increasingly popular practice is for certain governments to aid this process through an appropriate strategy and programs that serve the execution of that strategy. Because perceived time risk did not hold statistical significance in Togo, this phenomenon pinpoints that using MFS has little to do with the time spent. As such, service providers should preserve those features that ease the MFS application in the time-frame.

Lastly, the outcome of TOPSIS through an SEM-TOPSIS integrated study specifies that mobile money transfer (MMT) is indeed the predominant mobile financial service (MFS) alternative used in Togo followed by mobile payment (MP), while mobile banking (MB) is reflected as trifling. In general, MFS companies should concede that consumer trust and risk with their antecedent create a tremendous barrier to MFS transactions. This study still demonstrates that among the MFS companies, mobile money transfer companies are not powerless. It provides a practical guideline toward mobile financial service companies compared to the prevailing competitors within the related field such as online banking and ATM, for constructing more trust-based strategies to manipulate favorable consumer attitudes certainly, actions, and eventual transaction behavior whereas mitigating the perceived risk factors. Regarding MFS, companies offering mobile money transfer are suggested to sustain the adoption growth, while those performing mobile payment, mobile banking predominantly, are to bear their target consumers at the core of the business model by diversifying market strategy.

With regard to the above, we cannot ignore the network nature of the payments market, an essential characteristic of which is that the market's dynamics (all the services provided and their prices) depend on the cooperation between many actors. Therefore the optimizing and maximizing effect of the traditional, individual competition on efficiency does not necessarily prevail by itself [24]. This may account for why collaboration between actors plays a positive and decisive role in improvements in the fields of trust and encountered risks.

\subsection{Implication for Methodology and Theory}

This research remains the first to assess the multi-dimensional trust and perceived risk facet concurrently toward consumers' adoption decisions in mobile financial services while ranking their perspective.

The result obtained will open doors for scholars to explore further trust and perceived risk antecedents. It will support the theory of trust and risk literature in general and IT in particular, since many prior studies lacked conclusive outcomes about the directivity of the causative relationship between trust and perceived risk $[30,121,211]$. Our finding acknowledges the trust to be the potential predictor of risk in technology adoption. The scale items employed were greatly adopted from the prevailing studies in developed countries that are allied with technology acceptance adoption behavior, trust, and perceived risk. This section provides a crucial methodological implication for the marketing scholar, who might require a hint to cross-cultural appraisal concerning the application of scales, like those established in the United States and their relevance or relatedness in Togo. Our study outcomes not only enhance the clarification of mobile financial services adoption via the effect of trust and perceived risk but also hold some strategic implications for the global expansion of managerial implementation decision tools. This study provides a benchmark integrated methodology based on an SEM-MCDM application, which found lacking in the adoption decision in general. The theoreticians and practitioners should comprehend that the prominence of the integrated SEM-TOPSIS is rooted in its robustness to test multifarious postulations made, combined with the high level in ranking the countless alternatives when multiple criteria issues arise in decision making. 


\section{Limitation and Future Research}

Notwithstanding some contributions to the literature, practical, theoretical, and methodological applications, all research unavoidably entails drawbacks that should be addressed. Our study outcomes are unique to Togo, although they are similar to IT in general and mobile financial transactions studies, predominantly. Preferably, a longitudinal study on our framework might need to gain a better understanding of how the variables relay over time. We expect future research will address these concerns. This research displays that time risk concerns are not significant antecedents of perceived risk. We hope that future research will further elucidate the relationship between time risk issues and adoption behavior in other populaces and circumstances. Emphasizing multi-dimensional trust and perceived risk influences; this research projected to offer a wide-ranging still parsimonious decision-making model for MFS acceptance. However, the present model expounds only $13.1 \%$ of the variance in behavior to adopt. Future studies can incorporate additional variables, such as usefulness, perceived ease of use, and familiarity, in an attempt to enhance the explanatory power. Based on the respondent's educational background, our distributed questionnaire appears to be limited to the more educated and technically competent elements of society, who would be more inclined to accept MFS applications. Therefore, researchers interested in MFS for adoption and sustainability should focus more on the underbanked population where illiterate people might be found in the majority. Comparison studies between statistical methods (regression or structural equation modeling (SEM)) and the MCDM method are welcome for future work.

Author Contributions: K.G. worked on the original idea, conducted the investigation and the conceptualization, coordinated the methodology, data analysis, and writing the research paper; Y.X. worked on the investigation and provided resources; K.M.A. provided support on the investigation; L.K. supervised the work. All authors have read and agreed to the published version of the manuscript.

Funding: This research received no external funding.

Conflicts of Interest: The authors declare no conflict of interest.

\section{Appendix A}

Table A1. Measurement scales and items.

\begin{tabular}{l}
\hline Measurement Scales \\
\hline General Trust (G-trust) [221] \\
\hline Mobile financial services are trustworthy (G-trust1) \\
\hline Mobile financial services keep their promises(G-trust2) \\
\hline Mobile financial services keep customers' interests first(G-trust3) \\
\hline Dispositional Trust (DTrust) [222] \\
\hline It is easy for me to trust a person/thing. (DTrust1) \\
\hline My tendency to trust a person/thing is high. (DTrust2) \\
\hline I tend to trust a person/thing even though I have little knowledge of it. (DTrust3) \\
\hline Trusting someone or something is not difficult. (DTrust4) \\
\hline Technology Trust (TTrust) [223] \\
\hline I think the application of the mobile device for financial products or services will improve my decision on the financial transaction. \\
(TTrust1) \\
\hline I would like to try financial products such as money transfer using mobile devices application. (TTrust2) \\
\hline I think there is no technical risk in using mobile phone technology to access financial products. (TTrust3) \\
\hline Vendor Trust (Vtrust) [224] \\
\hline The vendor can safeguard the interests of consumers. (Vtrust1) \\
\hline The vendor hopes to maintain a good reputation. (Vtrust2) \\
\hline Overall, the vendor is credible. (Vtrust3) \\
\hline Perceived Risk (PRisk) [127] \\
\hline Using MFS would expose me to any kind of risk perception. (PRisk1) \\
\hline
\end{tabular}


Table A1. Cont.

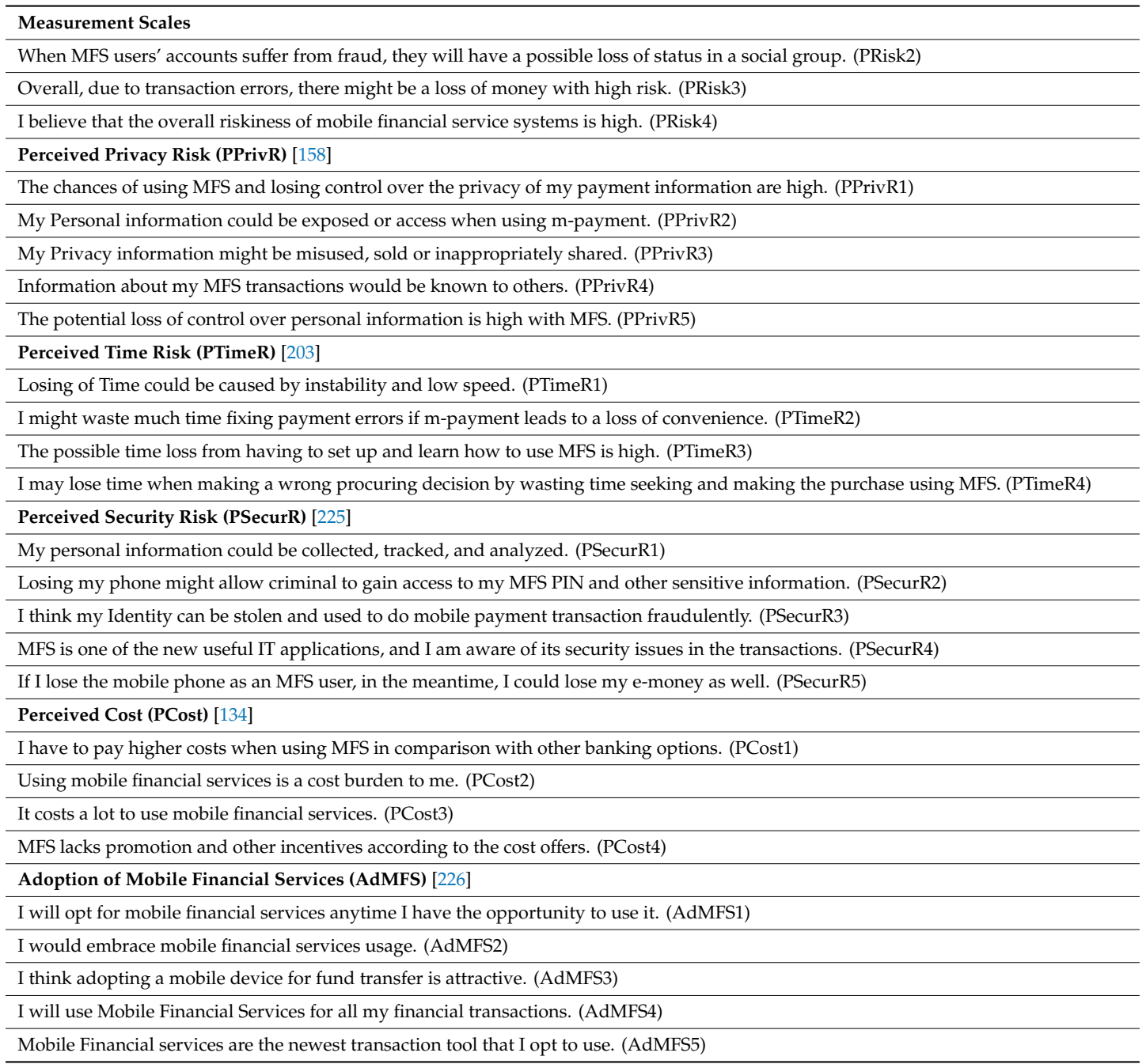

\section{References}

1. Hsu, C.L.; Wang, C.F.; Lin, J.C.C. Investigating customer adoption behaviours in Mobile Financial Services. Int. J. Mob. Commun. 2011, 9, 477. [CrossRef]

2. Oliveira, T.; Faria, M.; Thomas, M.A.; Popovič, A. Extending the understanding of mobile banking adoption: When UTAUT meets TTF and ITM. Int. J. Inf. Manag. 2014, 34, 689-703. [CrossRef]

3. Agarwal, R.; Prasad, J. Are individual differences germane to the acceptance of new information technologies? Decis. Sci. 1999, 30, 361-391. [CrossRef]

4. Afshan, S.; Sharif, A.; Waseem, N.; Frooghi, R. Internet banking in Pakistan: An extended technology acceptance perspective. Int. J. Bus. Inf. Syst. 2018, 27, 383. [CrossRef]

5. Al-Jabri, I.M.; Sohail, M.S. Mobile banking adoption: Application of diffusion of innovation theory. J. Electron. Commer. Res. 2012, 13, 379-391.

6. Abrahão, R.; Moriguchi, S.N.; Andrade, D.-F. Intention of Adoption of Mobile Payment: An analysis in the light of the Unified Theory of Acceptance and Use of Technology (UTAUT). Rev. Adm. Inov. 2016, 13, 221-230. [CrossRef]

7. Gbongli, K.; Dumor, K.; Kissi Mireku, K. MCDM technique to evaluating mobile banking adoption in the Togolese banking industry based on the perceived value: Perceived benefit and perceived sacrifice factors. Int. J. Data Min. Knowl. Manag. Process 2016, 6, 37-56.

8. Muñoz-Leiva, F.; Climent-Climent, S.; Liébana-Cabanillas, F. Determinants of Intention to Use The Mobile Banking Apps: An Extension of The Classic TAM Model. Span. J. Mark. 2017, 21, 25-38. [CrossRef] 
9. Yen, Y.S.; Wu, F.S. Predicting the adoption of mobile financial services: The impacts of perceived mobility and personal habit. Comput. Human Behav. 2016, 65, 31-42. [CrossRef]

10. Gbongli, K. A two-staged SEM-AHP technique for understanding and prioritizing mobile financial services perspectives adoption. Eur. J. Bus. Manag. 2017, 9, 107-120.

11. Lin, H.F. An empirical investigation of mobile banking adoption: The effect of innovation attributes and knowledge-based trust. Int. J. Inf. Manag. 2011, 31, 252-260. [CrossRef]

12. Mohammadi, H. A study of mobile banking loyalty in Iran. Comput. Human Behav. 2015, 44, 35-47. [CrossRef]

13. Safeena, R.; Date, H.; Kammani, A.; Hundewale, N. Technology Adoption and Indian Consumers: Study on Mobile Banking. Int. J. Comput. Theory Eng. 2012, 4, 1020-1024. [CrossRef]

14. Ooi, K.B.; Tan, G.W.H. Mobile technology acceptance model: An investigation using mobile users to explore smartphone credit card. Expert Syst. Appl. 2016, 59, 33-46. [CrossRef]

15. Gbongli, K.; Xu, Y.; Amedjonekou, K.M. Extended Technology Acceptance Model to Predict Mobile-Based Money Acceptance and Sustainability: A Multi-Analytical Structural Equation Modeling and Neural Network Approach. Sustainability 2019, 11, 3639. [CrossRef]

16. Jack, W.; Ray, A.; Suri, T. Transaction networks: Evidence from mobile money in Kenya. Am. Econ. Rev. 2013, 103, 356-361. [CrossRef]

17. Kikulwe, E.M.; Fischer, E.; Qaim, M. Mobile money, smallholder farmers, and household welfare in Kenya. PLoS ONE 2014, 9, e109804. [CrossRef]

18. Anderson, J. M-banking in developing markets: Competitive and regulatory implications. Info 2010, 12, 18-25. [CrossRef]

19. Assadi, D.; Cudi, A. Le potentiel d'inclusion financiere du Mobile Banking. Une etude exploratoire. Manag. Avenir 2011, 6, 227-243. [CrossRef]

20. Chaix, L.; Torre, D. Dominique Le double role du paiement mobile dans les pays en d'eveloppement. Rev. Econ. 2015, 66, 703-727.

21. MNB. National Bank of Hungary's Competitiveness Programme in 330 Points; Magyar Nemzeti Bank: Budapest, Hungary, 2019; ISBN 978-615-5318-26-9.

22. Couchoro, M.K. Challenges faced by MFIs in adopting Management information system during their growth phase: The case of Togo. Enterp. Dev. Microfinanc. 2016, 17, 115-131. [CrossRef]

23. Financial Afrik Faible Taux Du Mobile Banking Au Togo. Available online: http://news.alome.com/cc/24339. html (accessed on 14 March 2019).

24. Divéki, É.; Keszy-Harmath, Z.; Helmeczi, I. Innovative Payment Solutions, MNB Surveys No. 85; Magyar Nemzeti Bank: Budapest, Hungary, 2010; ISBN 1787-5293. (on-line).

25. Hassan Hosseini, M.; Fatemifar, A.; Rahimzadeh, M. Effective factors of the adoption of mobile banking services by customers. Kuwait Chapter Arab. J. Bus. Manag. Rev. 2015, 6, 1-13. [CrossRef]

26. Liébana-Cabanillas, F.; Sánchez-Fernández, J.; Muñoz-Leiva, F. Antecedents of the adoption of the new mobile payment systems: The moderating effect of age. Comput. Human Behav. 2014, 35, 464-478. [CrossRef]

27. Johnson, V.L.; Kiser, A.; Washington, R.; Torres, R. Limitations to the rapid adoption of M-payment services: Understanding the impact of privacy risk on M-Payment services. Comput. Human Behav. 2018, 79, 111-122. [CrossRef]

28. Gbongli, K.; Csordas, T.; Kissi Mireku, K. Impact of consumer multidimensional online trust-risk in adopting Togolese mobile money transfer services: Structural equation modelling approach. J. Econ. Manag. Trade 2017, 19, 1-17. [CrossRef]

29. Gbongli, K.; Peng, Y.; Ackah, O. Selection and ranking of perceived risk associated with mobile banking in West Africa: An AHP Approach from customers' perspective. Int. J. Sci. Eng. Res. 2016, 7, 80-86.

30. Mayer, R.C.; Davis, J.H.; Schoorman, F.D. An integrative model of organizational trust. Acad. Manag. Rev. 1995, 20, 709-734. [CrossRef]

31. Kovács, L.; David, S. Fraud risk in electronic payment transactions. J. Money Laund. Control. 2016, 19, 148-157. [CrossRef]

32. Gefen, D.; Benbasat, I.; Pavlou, P.A. A Research Agenda for Trust in Online Environments. J. Manag. Inf. Syst. 2008, 24, 275-286. [CrossRef]

33. Wells, J.D.; Campbell, D.E.; Valacich, J.S.; Featherman, M. The Effect of Perceived Novelty on the Adoption of Information Technology Innovations: A Risk/Reward Perspective. Decis. Sci. 2010, 41, 813-843. [CrossRef] 
34. Marett, K.; Pearson, A.W.; Pearson, R.A.; Bergiel, E. Using mobile devices in a high risk context: The role of risk and trust in an exploratory study in Afghanistan. Technol. Soc. 2015, 41, 54-64. [CrossRef]

35. Lee, K.C.; Chung, N. Understanding factors affecting trust in and satisfaction with mobile banking in Korea: A modified DeLone and McLean's model perspective. Interact. Comput. 2009, 21, 385-392. [CrossRef]

36. Gao, L.; Waechter, K.A. Examining the role of initial trust in user adoption of mobile payment services: An empirical investigation. Inf. Syst. Front. 2017, 19, 525-548. [CrossRef]

37. Alsaad, A.; Mohamad, R.; Ismail, N.A. The moderating role of trust in business to business electronic commerce (B2B EC) adoption. Comput. Human Behav. 2017, 68, 157-169. [CrossRef]

38. Lowry, P.B.; Vance, A.; Moody, G.; Beckman, B.; Read, A. Explaining and Predicting the Impact of Branding Alliances and Web Site Quality on Initial Consumer Trust of E-Commerce Web Sites. J. Manag. Inf. Syst. 2008, 24, 199-224. [CrossRef]

39. Luo, X.; Li, H.; Zhang, J.; Shim, J.P. Examining multi-dimensional trust and multi-faceted risk in initial acceptance of emerging technologies: An empirical study of mobile banking services. Decis. Support Syst. 2010, 49, 222-234. [CrossRef]

40. Park, S.; Tussyadiah, I.P. Multidimensional Facets of Perceived Risk in Mobile Travel Booking. J. Travel Res. 2017, 56, 854-867. [CrossRef]

41. Aktepe, A.; Ersöz, S.; Toklu, B. Customer satisfaction and loyalty analysis with classification algorithms and Structural Equation Modeling. Comput. Ind. Eng. 2015, 86, 95-106. [CrossRef]

42. Alzahrani, L.; Al-Karaghouli, W.; Weerakkody, V. Investigating the impact of citizens' trust toward the successful adoption of e-government: A multigroup analysis of gender, age, and internet experience. Inf. Syst. Manag. 2018, 35, 124-146. [CrossRef]

43. Shieh, L.F.; Chang, T.H.; Fu, H.P.; Lin, S.W.; Chen, Y.Y. Analyzing the factors that affect the adoption of mobile services in Taiwan. Technol. Forecast. Soc. Chang. 2014, 87, 80-88. [CrossRef]

44. Figueira, J.; Greco, S.; Ehrgott, M. Multiple criteria decision analysis: State of the art surveys. Mult. Criteria Decis. Anal. State Art Surv. 2005, 78, 859-890.

45. Valaskova, K.; Kramarova, K.; Bartosova, V. Multi Criteria Models Used in Slovak Consumer Market for Business Decision Making. Procedia Econ. Financ. 2015, 26, 174-182. [CrossRef]

46. Esearch, S.Y.R.; Koppius, O.R. Predictive Analytics in Information Systems Research. MIS Q. 2011, 35, 553-572.

47. Scott, J.E.; Walczak, S. Cognitive engagement with a multimedia ERP training tool: Assessing computer self-efficacy and technology acceptance. Inf. Manag. 2009, 46, 221-232. [CrossRef]

48. Hung, Y.H.; Chou, S.C.T.; Tzeng, G.H. Using MCDM methods to adopt and assess knowledge management. In Communications in Computer and Information Science; Springer: Berlin/Heidelberg, Germany, 2009; Volume 35, pp. 840-847.

49. Gupta, K.P.; Bhaskar, P.; Singh, S. Prioritization of factors influencing employee adoption of e-government using the analytic hierarchy process. J. Syst. Inf. Technol. 2017, 19, 116-137. [CrossRef]

50. Liou, J.J.H.; Tzeng, G.H. Comments on Multiple criteria decision making (MCDM) methods in economics: An overview. Technol. Econ. Dev. Econ. 2012, 18, 672-695. [CrossRef]

51. Gbongli, K.; Kovács, L. A Decision Analysis towards Mobile Financial Services Adoption and Sustainability in Togo: Structural Equation Modeling and TOPSIS Methodology. In Proceedings of the DSI 2019 Annual Meeting of Decision Sciences Institute, New Orleans, LA, USA, 23-25 November 2019; pp. 2080-2114.

52. Abu-Shanab, E.A.; Abu-Baker, A.N. Using and buying mobile phones in Jordan: Implications for future research and the Development of New Methodology. Technol. Soc. 2014, 38, 103-110. [CrossRef]

53. Laukkanen, T. Mobile banking. Int. J. Bank Mark. 2017, 35, 1042-1043. [CrossRef]

54. Hendricks, L.; Chidiac, S. Village Savings and Loans: A Pathway to Financial Inclusion for Africa's Poorest Households. Enterp. Dev. Microfinance 2011, 22, 134-146. [CrossRef]

55. Donovan, K. Mobile Money for Financial Inclusion. Inf. Commun. Dev. 2012, 61, 61-73. [CrossRef]

56. Dennehy, D.; Sammon, D. Trends in mobile payments research: A literature review. J. Innov. Manag. 2015, 3, 49-61. [CrossRef]

57. Lee, J.K.; Rao, H.R. Perceived risks, counter-beliefs, and intentions to use anti-/counter-terrorism websites: An exploratory study of government-citizens online interactions in a turbulent environment. Decis. Support Syst. 2007, 43, 1431-1449. [CrossRef] 
58. Li, H.; Sarathy, R.; Xu, H. The role of affect and cognition on online consumers' decision to disclose personal information to unfamiliar online vendors. Decis. Support Syst. 2011, 51, 434-445. [CrossRef]

59. Wisdom, J.P.; Chor, K.H.B.; Hoagwood, K.E.; Horwitz, S.M. Innovation adoption: A review of theories and constructs. Adm. Policy Ment. Health Ment. Health Serv. Res. 2014, 41, 480-502. [CrossRef]

60. Safeena, R.; Date, H.; Hundewale, N.; Kammani, A. Combination of TAM and TPB in Internet Banking Adoption. Int. J. Comput. Theory Eng. 2013, 5, 146-150. [CrossRef]

61. Yan, H.; Yang, Z. Examining mobile payment user adoption from the perspective of trust. Int. J. U E Serv. Sci. Technol. 2015, 8, 117-130. [CrossRef]

62. Slade, E.L.; Williams, M.D.; Dwivedi, Y.K. Mobile payment adoption: Classification and review of the extant literature. Mark. Rev. 2013, 13, 167-190. [CrossRef]

63. Tam, C.; Oliveira, T. Understanding mobile banking individual performance. Internet Res. 2017, $27,538-562$. [CrossRef]

64. Slade, E.; Williams, M.; Dwivedi, Y.; Piercy, N. Exploring consumer adoption of proximity mobile payments. J. Strateg. Mark. 2015, 23, 209-223. [CrossRef]

65. Fishbein, M.; Ajzen, I. Belief, Attitude, Intention and Behaviour: An Introduction to Theory and Research; Addison-Wesley: Reading, MA, USA, 1975. [CrossRef]

66. Ajzen, I. From intentions to action: A theory of planned behavior. In Action Control; Springer: Berlin/Heidelberg, Germany, 1985; pp. 11-39. ISBN 978-3-642-69746-3.

67. Barua, P. The Moderating Role of Perceived Behavioral Control: The Literature Criticism and Methodological Considerations. Int. J. Bus. Soc. Sci. 2013, 4, 57-59.

68. Davis, F.D.; Bagozzi, R.P.; Warshaw, P.R. User acceptance of computer technology: A comparison of two theoretical models. Manag. Sci. 1989, 35, 982-1003. [CrossRef]

69. Marangunić, N.; Granić, A. Technology acceptance model: A literature review from 1986 to 2013. Univers. Access Inf. Soc. 2015, 14, 81-95. [CrossRef]

70. Legris, P.; Ingham, J.; Collerette, P. Why do people use information technology? a critical review of the technology acceptance model. Inf. Manag. 2003, 40, 191-204. [CrossRef]

71. Mortenson, M.J.; Vidgen, R. A computational literature review of the technology acceptance model. Int. J. Inf. Manag. 2016, 36, 1248-1259. [CrossRef]

72. Davis, F. Perceived usefulness, perceived ease of use, and user acceptance of information technology. MIS $Q$. 1989, 13, 319-340. [CrossRef]

73. Gefen, D.; Straub, D.; Mack, J.; Distinguished, R. The relative importance of perceived ease of use in IS adoption: A study of e-commerce adoption. J. Assoc. Inf. Syst. 2000, 1, 1-30. [CrossRef]

74. Pavlou, P.A. Integrating trust in electronic commerce with the technology acceptance model: Model development and validation. In Proceedings of the Seventh Americas Conference in Information Systems AMCIS, Boston, MA, USA, 3-5 August 2001; pp. 816-822.

75. Waite, K.; Harrison, T. Online banking adoption: We should know better 20 years on. J. Financ. Serv. Mark. 2015, 20, 258-272. [CrossRef]

76. Thompson, R.L.; Higgins, C.A.; Howell, J.M. Personal Computing-Toward a Conceptual-Model of Utilization. MIS Q. 1991, 15, 125-143. [CrossRef]

77. Webster, J.; Martocchio, J.J. Microcomputer Playfulness: Development of a Measure with Workplace Implications. MIS Q. 1992, 16, 201. [CrossRef]

78. Suh, B.; Han, I. The Impact of Customer Trust and Perception ofSecurity Control on the Acceptance ofElectronic Commerce. Int. J. Electron. Commer. 2003, 7, 135-161.

79. Rogers, E.M. Diffusion of Innovations; Free Press of Glencoe: New York, NY, USA, 1962.

80. Plouffe, C.R.; Vandenbosch, M.; Hulland, J. Intermediating technologies and multi-group adoption: A comparison of consumer and merchant adoption intentions toward a new electronic payment system. J. Prod. Innov. Manag. 2001, 18, 65-81. [CrossRef]

81. Karahanna, E.; Straub, D.W.; Chervany, N.L.; Karahanna, E. Information technology adoption across time: A cross-sectional comparison of pre-adoption and post-adoption beliefs. MIS Q. 1999, 23, 183-213. [CrossRef]

82. Chen, L.-D.; Gillenson, M.L.; Sherrell, D.L. Enticing online consumers: An extended technology acceptance perspective. Inf. Manag. 2002, 39, 705-719. [CrossRef]

83. Lyytinen, K.; Damsgaard, J. What's Wrong with the diffusion of innovation theory? The case of a complex and networked technology. Reports Aalborg Univ. Dep. Comput. Sci. 2001, 187, 1-20. [CrossRef] 
84. Napaporn, K. Examining a Technology Acceptance Model of Internet Usage by Academics Within Thai Business Schools. Ph.D. Thesis, Victoria University, Melbourne, Australia, 2007.

85. Singleton, R.A.; Straits, B.C.; Straits, M.M. Approaches to Social Research, 2nd ed.; Oxford University Press: New York, NY, USA, 1993.

86. Taylor, S.; Todd, P.A. Understanding information technology usage: A test of competing models. Inf. Syst. Res. 1995, 6, 144-176. [CrossRef]

87. El-Kasheir, D.; Ashour, A.; Yacout, O. Factors affecting continued usage of internet banking among Egyptian customers. Commun. IBIMA 2009, 9, 252-263.

88. George, J.F. The theory of planned behavior and Internet purchasing. Internet Res. 2004, 14, $198-212$. [CrossRef]

89. Aboelmaged, M.G.; Gebba, R.T. Mobile Banking Adoption: An Examination of Technology Acceptance Model and Theory of Planned Behavior. Int. J. Bus. Res. Dev. 2013, 2, 35-50. [CrossRef]

90. Shaikh, A.A.; Karjaluoto, H. Mobile banking adoption: A literature review. Telemat. Inform. 2014, 32, $129-142$. [CrossRef]

91. Narteh, B.; Mahmoud, M.A.; Amoh, S. Customer behavioural intentions towards mobile money services adoption in Ghana. Serv. Ind. J. 2017, 37, 426-447. [CrossRef]

92. Alalwan, A.A.; Dwivedi, Y.K.; Rana, N.P. Factors influencing adoption of mobile banking by Jordanian bank customers: Extending UTAUT2 with trust. Int. J. Inf. Manag. 2017, 37, 99-110. [CrossRef]

93. Afawubo, K.; Agbagla, M.; Couchoro, K.M.; Gbandi, T. Socioeconomic determinants of the mobile money adoption process: The case of Togo. Cah. Rech. 2017, 17, 1-23.

94. Gefen, D.; Straub, D. Managing User Trust in B2C e-Services. e-Serv. 2003, 2, 7-24. [CrossRef]

95. Mcknight, D.H.; Chervany, N.L. What trust means in e-commerce customer relationships: An interdisciplinary conceptual typology. Int. J. Electron. Commer. 2001, 6, 35-59. [CrossRef]

96. Tan, F.B.; Sutherland, P. Online Consumer Trust: A Multi-Dimensional Model. J. Electron. Commer. Organ. 2004, 2, 40-58. [CrossRef]

97. Vidotto, G.; Massidda, D.; Noventa, S.; Vicentini, M. Trusting beliefs: A functional measurement study. Psicologica 2012, 33, 575-590.

98. Nor, K.M.; Pearson, J.M. An Exploratory Study Into The Adoption of Internet Banking in a Developing Country: Malaysia. J. Internet Commer. 2008, 7, 29-73. [CrossRef]

99. Schoorman, F.D.; Mayer, R.C.; Davis, J.H. An Integrative Model of Organizational Trust: Past, Present, and Future. Acad. Manag. Rev. 2007, 32, 344-354. [CrossRef]

100. Hallikainen, H.; Laukkanen, T. National culture and consumer trust in e-commerce. Int. J. Inf. Manag. 2018, 38, 97-106. [CrossRef]

101. Gefen, D.; Karahanna, E.; Straub, D.W. Trust and TAM in online shopping: An integrated mode. MIS Q. 2003, 27, 51-90. [CrossRef]

102. Mcknight, D.H.; Carter, M.; Thatcher, J.B. Trust in a Specific Technology: An Investigation of Its Components and Measures Trust in a specific technology: An investigation of its components and measures. ACM Trans. Manag. Inform. Syst. 2011, 2, 1-25. [CrossRef]

103. Muir, B.M.; Moray, N. Trust in automation. Part II. Experimental studies of trust and human intervention in a process control simulation. Ergonomics 1996, 39, 429-460. [CrossRef] [PubMed]

104. Misiolek, N.; Zakaria, N.; Zhang, P. Trust in organizational acceptance of information technology: A conceptual model and preliminary evidence. In Proceedings of the Decision Sciences Institute 33rd Annual Meeting, San Diego, CA, USA, 23-26 November 2002; pp. 1-7.

105. Meng, D.; Min, Q.; Li, Y. Study on trust in mobile commerce adoption-A conceptual model. In Proceedings of the International Symposium on Electronic Commerce and Security, Guangzhou, China, 3-5 August 2008; pp. 246-249.

106. Min, Q.; Meng, D.; Zhong, Q. An empirical study on trust in mobile commerce adoption. In Proceedings of the 2008 IEEE International Conference on Service Operations and Logistics, and Informatics, Beijing, China, 12-15 October 2008; Volume 1, pp. 659-664.

107. Lankton, N.K.; Harrison McKnight, D.; Wright, R.T.; Thatcher, J.B. Using expectation disconfirmation theory and polynomial modeling to understand trust in technology. Inf. Syst. Res. 2016, 27, 197-213. [CrossRef]

108. Bailey, B.P.; Gurak, L.J.; Konstan, J. Trust in Cyberspace. In Human Factors and Web Development, 2nd ed.; Ratner, J., Ed.; Lawrence Erlbaum Associates: Mahwah, NJ, USA, 2002. 
109. Pavlou, P.A.; Liang, H.; Xue, Y. Understanding and Mitigating Uncertainty in Online Exchnge Relationships: A Principle-Agent Perspective. MIS Q. 2007, 31, 105-136. [CrossRef]

110. Liu, Z.; Min, Q.; Ji, S. An empirical study on mobile banking adoption: The role of trust. In Proceedings of the 2009 Second International Symposium on Electronic Commerce and Security, Nanchang, China, 22-24 May 2009; Volume 2, pp. 7-13.

111. Yang, S. Role of transfer-based and performance-based cues on initial trust in mobile shopping services: A cross-environment perspective. Inf. Syst. E-Bus. Manag. 2016, 14, 47-70. [CrossRef]

112. Yang, S.; Chen, Y.; Wei, J. Understanding consumers' web-mobile shopping extension behavior: A trust transfer perspective. J. Comput. Inf. Syst. 2015, 55, 78-87. [CrossRef]

113. Nilashi, M.; Ibrahim, O.; Reza Mirabi, V.; Ebrahimi, L.; Zare, M. The role of Security, Design and Content factors on customer trust in mobile commerce. J. Retail. Consum. Serv. 2015, 26, 57-69. [CrossRef]

114. Rogers, E.M. Diffusion of Innovations, 3rd ed.; Free Press: New York, NY, USA, 1983.

115. Bhattacherjee, A. Individual Trust in Online Firms: Scale Development and Initial test. J. Manag. Inf. Syst. 2002, 19, 211-242.

116. Bauer, R.A. Consumer behavior as risk taking. In Risk Taking and Information Handling in Consumer Behavior; Harvard University Press: Cambridge, MA, USA, 1960; pp. 389-398.

117. Cunningham, S.M. The Major Dimensions of Perceived Risk, in Risk Taking and Information Handling in Consumer Behavior; Harvard University: Cambridge, MA, USA, 1967; Volume 82-108.

118. Costigan, R.D.; Ilter, S.S.; Berman, J.J. A Multi-Dimensional Study of Trust in Organizations. J. Manag. 1998, 10, 303-316.

119. Johnson-George, C.; Swap, W.C. Measurement of specific interpersonal trust: Construction and validation of a scale to assess trust in a specific other. J. Personal. Soc. Psychol. 1982, 43, 1306-1317. [CrossRef]

120. Koller, M. Risk as a Determinant of Trust. Basic Appl. Soc. Psych. 1988, 9, 265-276. [CrossRef]

121. Gefen, D.; Srinivasan Rao, V.; Tractinsky, N. The conceptualization of trust, risk and their electronic commerce: The need for clarifications. In Proceedings of the 36th Annual Hawaii International Conference on System Sciences, HICSS 2003, Big Island, HI, USA, 6-9 January 2003.

122. Jarvenpaa, S.L.; Tractinsky, N.; Vitale, M. Consumer Trust in an Internet Store. Inf. Technol. Manag. 2000, 1, 45-71. [CrossRef]

123. Grandison, T.; Sloman, M. A survey of trust in internet applications. IEEE Commun. Surv. Tutor. 2000, 3, 2-16. [CrossRef]

124. Johnston, A.C.; Warkentin, M. The Online Consumer Trust Construct: A Web Merchant Practitioner Perspective. In Proceedings of the 7th Annual Conference of the Southern Association for Information Systems, Savannah, GA, USA, 27-28 February 2004; pp. 220-226.

125. Merhi, M.; Hone, K.; Tarhini, A. A cross-cultural study of the intention to use mobile banking between Lebanese and British consumers: Extending UTAUT2 with security, privacy and trust. Technol. Soc. 2019, 59, 101151. [CrossRef]

126. Swaminathan, V.; Lepkowska-White, E.; Rao, B.P. Browsers or Buyers in Cyberspace? An Investigation of Factors Influencing Electronic Exchange. J. Comput. Commun. 1999, 5. [CrossRef]

127. Featherman, M.S.; Pavlou, P.A. Predicting e-services adoption: A perceived risk facets perspective. Int. J. Hum. Comput. Stud. 2003, 59, 451-474. [CrossRef]

128. Bellman, S.; Lohse, G.L.; Johnson, E.J. Predictors of online buying behavior. Commun. ACM 1999, 42, 32-38. [CrossRef]

129. Murray, K.B.; Schlacter, J.L. The impact of services versus goods on consumers' assessment of perceived risk and variability. J. Acad. Mark. Sci. 1990, 18, 51-65. [CrossRef]

130. Lee, M.C. Predicting Behavioural Intention to Use Online Banking. In Proceedings of the 19th International Conference on Information Management, Taipei, Taiwan, 13-14 November 2008.

131. Yang, A.S. Exploring Adoption difficulties in mobile banking services. Can. J. Adm. Sci. 2009, 26, 136-149. [CrossRef]

132. Cruz, P.; Neto, L.B.F.; Muñoz-Gallego, P.; Laukkanen, T. Mobile banking rollout in emerging markets: Evidence from Brazil. Int. J. Bank Mark. 2010, 28, 342-371. [CrossRef]

133. Yao, H.; Zhong, C. The analysis of influencing factors and promotion strategy for the use of mobile banking/L'analyse d'influencer des facteurs et la stratégie de promotion pour l'usage des opérations bancaires mobiles. Can. Soc. Sci. 2011, 7, 60-63. 
134. Luarn, P.; Lin, H.-H. Toward an understanding of the behavioral intention to use mobile banking. Comput. Human Behav. 2005, 21, 873-891. [CrossRef]

135. McKnight, D.H.; Cummings, L.L.; Chervany, N.L. Initial trust formation in new organizational relationships. Acad. Manag. Rev. 1998, 23, 473-490. [CrossRef]

136. McKnight, D.H.; Choudhury, V.; Kacmar, C. Developing and validating trust measures for e-commerce: An integrative typology. Inf. Syst. Res. 2002, 13, 334-359. [CrossRef]

137. Gefen, D. E-commerce: The role of familiarity and trust. Omega 2000, 28, 725-737. [CrossRef]

138. Kim, K.K.; Prabhakar, B. Initial Trust and the Adoption of B2C e-Commerce: The Case of Internet Banking. ACM SIGMIS Database 2004, 35, 50-64. [CrossRef]

139. Guangming, Y.; Yuzhong, M. A research on the model of factors influencing consumer trust in mobile business. In Proceedings of the 2011 International Conference on E-Business and E-Government, Shanghai, China, 6-8 May 2011; pp. 1-5.

140. Pratt, J.W. Risk Aversion in the Small and in the Large. Econometrica 1964, 32, 122-136. [CrossRef]

141. Kogan, N.; Wallach, M.A. Risk-Taking: A Study in Cognition and Personality; Rhinehart \& Winston: New York, NY, USA, 1964.

142. Cox, D.F. Risk Taking and Information Handling in Consumer Behavior; Harvard University: Boston, MA, USA, 1967.

143. Bonoma, T.V.; Johnston, W.J. Decision making under uncertainty: A direct measurement approach. J. Consum. Res. 1979, 6, 177. [CrossRef]

144. Currim, I.S.; Sarin, R.K. A Procedure for Measuring and Estimating Consumer Preferences Under Uncertainty. J. Mark. Res. 1983, 20, 249-256. [CrossRef]

145. Cunningham, L.F.; Gerlach, J.H.; Harper, M.D.; Young, C.E. Perceived risk and the consumer buying process: Internet airline reservations. Int. J. Serv. Ind. Manag. 2005, 16, 357-372. [CrossRef]

146. Lee, M.S.Y.; McGoldrick, P.J.; Keeling, K.A.; Doherty, J. Using ZMET to explore barriers to the adoption of 3G mobile banking services. Int. J. Retail Distrib. Manag. 2003, 31, 340-348. [CrossRef]

147. Kim, K.K.; Prabhakar, B. Initial trust, perceived risk, and the adoption of internet banking. ICIS 2000 Proc. 2000, 55, 537-543.

148. Laforet, S.; Li, X. Consumers' attitudes towards online and mobile banking in China. Int. J. Bank Mark. 2005, 23, 362-380. [CrossRef]

149. Lee, E.; Kwon, K.; Schumann, D.W. Segmenting the non-adopter category in the diffusion of internet banking. Int. J. Bank Mark. 2005, 23, 414-437. [CrossRef]

150. Tan, M.; Teo, T.S.H. Factors Influencing the Adoption of Internet Banking. J. AIS 2000, 1, 1-42. [CrossRef]

151. Liang, T.-P.; Huang, J.-S. An empirical study on consumer acceptance of products in electronic markets: A transaction cost model. Decis. Support Syst. 1998, 24, 29-43. [CrossRef]

152. Liao, Z.; Cheung, M.T. Internet-based e-shopping and consumer attitudes: An empirical study. Inf. Manag. 2001, 38, 299-306. [CrossRef]

153. Kim, D.J.; Ferrin, D.L.; Rao, H.R. A trust-based consumer decision-making model in electronic commerce: The role of trust, perceived risk, and their antecedents. Decis. Support Syst. 2008, 44, 544-564. [CrossRef]

154. Pavlou, P.A. Consumer intentions to adopt electronic commerce-Incorporating trust and risk in the technology acceptance model. Int. J. Electron. Commer. 2003, 7, 101-134.

155. Dowling, G.R.; Staelin, R. A Model of Perceived Risk and Intended Risk-Handling Activity. J. Consum. Res. 1994, 21, 119. [CrossRef]

156. Assael, H. Consumer Behavior and Marketing Action, 6th ed.; South-Western College Publishing: Cincinnati, OH, USA, 1998.

157. Coulter, R.A.; Price, L.L.; Feick, L. Rethinking the Origins of invoivement and Brand Commitment: Insights from Postsociaiist Centrai Europe. J. Consum. Res. 2003, 30, 151-169. [CrossRef]

158. Jarvenpaa, S.L.; Tractinsky, N. Consumer trust in an Internet store: A cross cultural validation. J. Comput. Mediat. Commun. 1999, 5, 1-5. [CrossRef]

159. Cooper, D.R.; Schindler, P.S. Business Research Methods, 8th ed.; McGraw-Hill Irwin: Boston, MA, USA, 2003; ISBN 0199284989.

160. Straub, D.; Boudreau, M.; Gefen, D. Validation Guidelines for IS Positivist Validation Guidelines for IS Positivist. Commun. Assoc. Inf. Syst. 2004, 13, 380-427. 
161. Gbongli, K. Integrating AHP-TOPSIS approach on prioritizing self-service technology (SST) decision making in financial institution (Togo). Br. J. Math. Comput. Sci. 2016, 16, 1-22.

162. N'Guissan, Y. Résultats définitifs du 4ème recensement général (RGPH4) au Togo. Available online: http://www.stat-togo.org/index.php/rgph (accessed on 25 March 2018).

163. Yamane, T. Statistics: An introductory analysis. Harper Row 1967, 60, 886.

164. Kumar Mittal, V.; Singh Sangwan, K. Development of a structural model of environmentally conscious manufacturing drivers. J. Manuf. Technol. Manag. 2014, 25, 1195-1208. [CrossRef]

165. Hair, J.F.; Black, W.C.; Babin, B.J.; Anderson, R.E.; Tatham, R.L. Multivariate Data Analysis, 7th ed.; Pearson: New York, NY, USA, 2010; ISBN 9788577804023.

166. Chin, W. The partial least squares approach to structural equation modeling. Mod. Methods Bus. Res. 1998, 295, 295-336.

167. Anderson, J.C.; Gerbing, D.W. Structural equation modeling in practice: A review and recommended two-step approach. Psychol. Bull. 1988, 103, 411-423. [CrossRef]

168. Schumacher, R.E.; Lomax, R.G. A Beginner's Guide to Structural Equation Modeling; Lawrence Erlbaum Associates: Mahwah, NJ, USA, 1996.

169. Hair, J.F.; Black, W.; Babin, B.; Anderson, R.; Tatham, R. Multivariate Data Analysis, 6th ed.; Pearson Prentice Hall, Pearson Education, Inc.: Upper Saddle River, NJ, USA, 2006; Volume 6, ISBN 909003868X.

170. Aloini, D.; Martini, A.; Pellegrini, L. A structural equation model for continuous improvement: A test for capabilities, tools and performance. Prod. Plan. Control Manag. Oper. 2011, 22, 628-648. [CrossRef]

171. Kaiser, H.F. An index of factorial simplicity. Psychometrika 1974, 39, 31-36. [CrossRef]

172. Campbell, D.T.; Fiske, D.W. Convergent and discriminant validity by the multitrait-multimethod matrix. Psychol. Bull. 1959, 56, 81-105. [CrossRef] [PubMed]

173. Zhou, T. Examining mobile banking user adoption from the perspectives of trust and flow experience. Inf. Technol. Manag. 2012, 13, 27-37. [CrossRef]

174. Fornell, C.; Larcker, D.F. Structural Equation Models with Unobservable Variables and Measurement Error: Algebra and Statistics. J. Mark. Res. 1981, 18, 382-388. [CrossRef]

175. Hair, J.F.; Anderson, R.E.; Tatham, R.L.; Black, W.C. Multivariate Data Analysis, 7th ed.; Prentice Hall: Upper Saddle River, NJ, USA, 2010. [CrossRef]

176. Zhou, T.; Lu, Y.; Wang, B. Integrating TTF and UTAUT to explain mobile banking user adoption. Comput. Hum. Behav. 2010, 26, 760-767. [CrossRef]

177. Hwang, Y. User experience and personal innovativeness: An empirical study on the Enterprise Resource Planning systems. Comput. Human Behav. 2014, 34, 227-234. [CrossRef]

178. Podsakoff, P.M.; MacKenzie, S.B.; Lee, J.; Podsakoff, N.P. Common method biases in behavioral research: A critical review of the literature and recommended remedies. J. Appl. Psychol. 2003, 88, 879-903. [CrossRef]

179. Davidov, E. A cross-country and cross-time comparison of the human values measurements with the second round of the European social survey. Surv. Res. Methods 2008, 2, 33-46.

180. Hwang, C.-L.; Yoon, K. Multiple Attribute Decision Making: Methods and Applications: A State-of-the-Art Survey; Springer: Berlin, Germany; New York, NY, USA, 1981; Volume 259.

181. Patil, S.K.; Kant, R. A fuzzy AHP-TOPSIS framework for ranking the solutions of Knowledge Management adoption in Supply Chain to overcome its barriers. Expert Syst. Appl. 2014, 41, 679-693. [CrossRef]

182. Mahdevari, S.; Shahriar, K.; Esfahanipour, A. Human health and safety risks management in underground coal mines using fuzzy TOPSIS. Sci. Total Environ. 2014, 488, 85-99. [CrossRef]

183. Dhull, S.; Narwal, M.S. Prioritizing the Drivers of Green Supply Chain Management in Indian Manufacturing Industries Using Fuzzy TOPSIS Method: Government, Industry, Environment, and Public Perspectives. Process Integr. Optim. Sustain. 2018, 2, 47-60. [CrossRef]

184. Vinodh, S.; Prasanna, M.; Hari Prakash, N. Integrated Fuzzy AHP-TOPSIS for selecting the best plastic recycling method: A case study. Appl. Math. Model. 2014, 38, 4662-4672. [CrossRef]

185. Behzadian, M.; Khanmohammadi Otaghsara, S.; Yazdani, M.; Ignatius, J. A state-of the-art survey of TOPSIS applications. Expert Syst. Appl. 2012, 39, 13051-13069. [CrossRef]

186. Lin, C.T.; Tsai, M.C. Location choice for direct foreign investment in new hospitals in China by using ANP and TOPSIS. Qual. Quant. 2010, 44, 375-390. [CrossRef]

187. Shih, H.S.; Shyur, H.J.; Lee, E.S. An extension of TOPSIS for group decision making. Math. Comput. Model. 2007, 45, 801-813. [CrossRef] 
188. Shipley, M.F.; de Korvin, A.; Obid, R. A decision making model for multi-attribute problems incorporating uncertainty and bias measures. Comput. Oper. Res. 1991, 18, 335-342. [CrossRef]

189. Punniyamoorty, M.; Mathiyalagan, P.; Lakshmi, G. A combined application of structural equation modeling (SEM) and analytic hierarchy process (AHP) in supplier selection. Benchmarking An Int. J. 2012, 19, 70-92. [CrossRef]

190. Payne, R.; Clark, M. Dispositional and situational determinants of trust in two types of managers. Int. J. Hum. Resour. Manag. 2003, 14, 128-138. [CrossRef]

191. Salam, A.F.; Iyer, L.; Palvia, P.; Singh, R. Trust in e-commerce. Commun. ACM 2005, 48, 72-77. [CrossRef]

192. Lippert, S.K.; Forman, H. A supply chain study of technology trust and antecedents to technology internalization consequences. Int. J. Phys. Distrib. Logist. Manag. 2006, 36, 271-288. [CrossRef]

193. Pavlou, P.; Ratnasingam, P. Technology trust in B2B electronic commerce: Conceptual foundations. In Business Strategies for Information Technology Management; Kangas, K., Ed.; Idea Group Publishing: Hershey, PA, USA, 2001; pp. 200-215.

194. Aldridge, A.; White, M.; Forcht, K. Security considerations of doing business via the Internet: Cautions to be considered. Internet Res. 1997, 7, 9-15. [CrossRef]

195. Pavlou, A.P. Consumer acceptance of electronic commerce: Integrating trust and risk with the technology acceptance model. Int. J. Electron. Commer. 2003, 7, 69-103.

196. Cheung, C.; Lee, M.K.O. Trust in Internet Shopping: A Proposed Model and Measurement Instrument. In Americas Conference on Information Systems; AIS Electronic Library: Long Beach, CA, USA, 2000; pp. 680-689.

197. Kesharwani, A.; Bisht, S.S. The impact of trust and perceived risk on internet banking adoption in India: An extension of technology acceptance model. Int. J. Bank Mark. 2012, 30, 303-322. [CrossRef]

198. Fukuyama, F. Trust: The Social Virtues and the Creation of Prosperity. In Trust the Social Virtues and the Creation of Prosperity; Free Press: New York, NY, USA, 1995; p. 457. [CrossRef]

199. Ratnasingham, P.; Kumar, K. Trading partner trust in electronic commerce participation. ICIS 2000 Proc. 2000, 56, 544-552.

200. Zikmund, G.W.; Scott, E.J. A Multivariate Analysis of Perceived Risk Self-Confidence and Information Sources. N. Am. Adv. Consum. Res. 1974, 1, 406-416.

201. Boksberger, P.E.; Bieger, T.; Laesser, C. Multidimensional analysis of perceived risk in commercial air travel. J. Air Transp. Manag. 2007, 13, 90-96. [CrossRef]

202. Choffee, S.H.; McLeod, J.M. Consumer Decisions and Information Use; Ward, S., Robertson, T.S., Eds.; Consumer behavior: Theoretical sources; Prentice-Hall Inc.: Englewood Cliffs, NJ, USA, 1973.

203. Zhang, L.; Tan, W.; Xu, Y.; Tan, G. Dimensions of perceived risk and their influence on consumers' purchasing behavior in the overall process of B2C. In Engineering Education and Management; Zhang, L., Zhang, C., Eds.; Springer: Berlin/Heidelberg, Germany, 2012; Volume 111, pp. 1-11.

204. Chakuthip, A.; Brunetto, Y.; Rod, F.-W.; Sheryl, R. Trust, Social Network and Electronic Commerce Adoption. In Handbook of Research on Electronic Collaboration and Organizational Synergy; IGI Global: Hershey, NY, USA, 2007; pp. 452-471. [CrossRef]

205. Grabner-Kräuter, S.; Kaluscha, E.A. Empirical research in on-line trust: A review and critical assessment. Int. J. Hum. Comput. Stud. 2003, 58, 783-812. [CrossRef]

206. Rotter, J.B. Generalized expectancies for interpersonal trust. Am. Psychol. 1971, 26, 443-452. [CrossRef]

207. Mitchell, V. Consumer perceived risk: Conceptualisations and models. Eur. J. Mark. 1999, 33, $163-195$. [CrossRef]

208. Manchiraju, S.; Vudayagiri, G.; Garg, G. Capgemini Top 10 trends in payment in 2016. Available online: https://www.capgemini.com/resource-file-access/resource/pdf/payments_trends_2016.pdf (accessed on 20 September 2019).

209. De Fouchier, R.; Larduinat, X. Connected living: How technology could impact daily lives by 2025-An International Study of Consumers Expectations for the Future of Mobile Technology. Available online: http://www.gemalto.com/brochures-site/download-site/Documents/documentgating/telwp-connected-living-2025.pdf (accessed on 25 September 2019).

210. Hosmer, L.T. Trust: The connecting link between organizational theory and philosophical ethics. Acad. Manag. Rev. 1995, 20, 379-403. [CrossRef]

211. Rousseau, D.M.; Sitkin, S.B.; Burt, R.S.; Camerer, C. Not so different after all: A cross-discipline view of trust. Acad. Manag. Rev. 1998, 23, 393-404. [CrossRef] 
212. Luhmann, N. Trust and Power. Coop. Trust 1979, 8, 208. [CrossRef]

213. Konovsky, M.A.; Pugh, S.D. Citizenship behavior and social exchange. Acad. Manag. J. 1994, 37, 656-669.

214. Rossiter, C.M.; Barnett, P.W. Communicating Personally: A Theory of Interpersonal Communication and Human Relationships; The Bobbs-Merrill Company, Inc.: Indianapolis, IN, USA, 1975.

215. Schurr, P.H.; Ozanne, J.L. Influences on Exchange Processes: Buyers' Preconceptions of a Seller's Trustworthiness and Bargaining Toughness. J. Consum. Res. 1985, 11, 939. [CrossRef]

216. Fox, C.; Causey, E.; Cencula, D. Study of Mobile Banking \& Payments, 3rd ed.; First Annapolis Consulting, Inc.: Annapolis, MD, USA, 2016.

217. Gavade, R.K. Multi-Criteria Decision Making: An overview of different selection problems and methods. Int. J. Comput. Sci. Inf. Technol. 2014, 5, 5643-5646.

218. Abdul-Hamid, I.K.; Shaikh, A.A.; Boateng, H.; Hinson, R.E. Customers' Perceived Risk and Trust in Using Mobile Money Services—an Empirical Study of Ghana. Int. J. E-Bus. Res. 2019, 15, 1-19. [CrossRef]

219. José Liébana-Cabanillas, F.; Sánchez-Fernández, J.; Muñoz-Leiva, F. Role of gender on acceptance of mobile payment. Ind. Manag. Data Syst. 2014, 114, 220-240. [CrossRef]

220. Kovács, L.; Terták, E. Financial Literacy, Panacea or Placebo-A Central European Perspective; Verlag Dashöfer: Bratislava, Slovakia, 2016.

221. Zhou, T. An empirical examination of continuance intention of mobile payment services. Decis. Support Syst. 2013, 54, 1085-1091. [CrossRef]

222. Lee, M.K.O.; Turban, E.; Matthew, K.O.; Lee, E.T. A trust model for consumer internet shopping. Int. J. Electron. Commer. 2001, 6, 75-91. [CrossRef]

223. Cheng, X.; Macaulay, L. Exploring Individual Trust Factors in Computer Mediated Group Collaboration: A Case Study Approach. Gr. Decis. Negotiat. 2014, 23, 533-560. [CrossRef]

224. Fang, Y.; Qureshi, I.; Sun, H.; McCole, P.; Ramsey, E.; Lim, K.H. Trust, Satisfaction, and Online Repurchase Intention: The Moderating Role of Perceived Effectiveness of E-Commerce Institutional Mechanisms. MIS Q. 2014, 38, 407-427. [CrossRef]

225. Tsiakis, T. Consumers' issues and concerns of perceived risk of information security in online framework. The marketing strategies. Procedia Soc. Behav. Sci. 2012, 62, 1265-1270. [CrossRef]

226. Sharma, S.K.; Govindaluri, S.M.; Al-Muharrami, S.; Tarhini, A. Predicting mobile banking adoption: A neural network approach. J. Enterp. Inf. Manag. 2016, 29, 222-237.

(C) 2020 by the authors. Licensee MDPI, Basel, Switzerland. This article is an open access article distributed under the terms and conditions of the Creative Commons Attribution (CC BY) license (http://creativecommons.org/licenses/by/4.0/). 